\title{
Design of Knowledge Models for Teaching Experimental Sciences at University
}

\author{
Maider Pérez de Villarreal \\ Psychology and Pedagogy Department, Public University of Navarra, Spain
}

Copyright $@ 2018$ by authors, all rights reserved. Authors agree that this article remains permanently open access under the terms of the Creative Commons Attribution License 4.0 International License

\begin{abstract}
Teaching Experimental Sciences is a compulsory subject in the Bachelor's Degree in Primary Education (BDPE). It belongs to the discipline of Education and to the field of "Knowledge of the social and natural environment", and consists of a total of 24 ECTS, of which 6 ECTS correspond to "Teaching Natural Sciences" (TNS). This subject is taught in the second half of the second year of the BDPE. The aim of this work has been the presentation of this subject as a Knowledge Model (KM) including interlinked Concept Maps (CCMM) with different levels of deepness of the developed topics; and to check if this new way of presentation has a positive effect on students' satisfaction towards the learning and teaching process (LTP) by inquiring about the meaningful learning and coherency of the contents by using CCMM. Results show although it is difficult to change from the comfort zone at the beginning, when students start using Cmap Tools for creating their own Knowledge Models, they finish learning meaningfully and understanding better the whole subject, find it easier to study for the evaluation and get to the domain of Knowledge by reaching basic, general and specific skills.
\end{abstract}

Keywords Teaching Natural Sciences (TNS), Knowledge Models (KM), Meaningful Learning, Concept Maps (CCMM), Cmap Tools

\section{Introduction}

New Information and Communication Technologies (ICTs) are providing resources which are changing the current educational landscape by undergoing a change not only in methodologies, but in teaching styles and teaching methods.

González et al. [17] warned the current educational context required a shift from the predominant positive-behaviorist model which favored mechanical rote learning, and therefore the generation of misconceptions, towards another cognitive-constructivist, which would stimulate meaningful learning. This new paradigm would allow students to build and master knowledge, becoming creative and critical citizens (Meichenbaum and Biemiller [23]). The $21^{\text {st }}$ faces a number of challenges: some come from the so-called society of knowledge and information, which can be summarized in a change of an ethic of obligation for another of responsibility; widespread use of information and communication technologies, the so called ICT; and the requirement of a school, in generic terms, of quality, accountable to society and which encourages students to get universal literacy, motivation to learn and discipline for long life learning. Other challenges come from the implementation of the European High Education Area (EHEA) which implies a change in the model of teaching / learning, shaping a new role not only for teachers, but also for students, and affects the redesign of the subjects contained in the called Teachers' Guides, defined by Zabalza [43]. In this new paradigm, students play an active role not only learning about the product but through the process itself (metacognition). The teacher's responsibility is primarily to create conditions that facilitate students the ability to transform information in useful, substantive and transparent knowledge, which is incorporated and well-articulated in their long-term memory.

The assessment in this new educational scenario plays a key role in promoting continuous improvement, consolidating the strengths and correcting weaknesses. According to Novak [32], such evaluation should take two dimensions: firstly measure what students know and secondly, assess how their cognitive structure has changed in relation to such knowledge, by evaluating the necessary conceptual change as Posner et al. [36] set down. It is noteworthy in this model, the teaching dimension (emphasis on teaching or what is taught) is subordinated to what it is learnt and how students learn better and get skills for their future. Under this focus, the teaching-learning process (TLP) changes into the learning-teaching process (LTP). That is to say, education is a concept based in learning and student-centered. Primary and Secondary Schools as well as Universities have to use their potential 
in order to promote teaching/learning quality, define adequate learning results and point the way to get them as explained by Pérez de Villarreal [35] and the best way is starting teaching basic CCMM in the early childhood.

The theoretical framework of Ausubel, Novak and Gowin is suited as well as their methodological application through the construction of Concept Maps (CCMM) and Gowin's epistemological "Vee" diagram. CCMM and Vee diagrams are metacognitive tools which help enhancing the conceptual change needed in the way of educating in knowledge. In the 80's, Ausubel et al. [3] developed his theory of meaningful learning remarking that: " the student must demonstrate a willingness to relate substantial and not arbitrarily the new information in his cognitive structure, as the learning material is potentially significant for him; this is, relatable with his knowledge structure on a non-arbitrary basis". Substantial and not arbitrary relationship should be understood in the way that the ideas relate to an existing relevant aspect of the student's cognitive structure, such as an image, a significant symbol, a concept or a proposition. This means that in the educational process, it is important to consider what the student already knows, so that he can establish a relationship with what he must learn. This process takes place if the student has in his cognitive structure concepts, such as the following: stable and defined ideas and propositions, with which new information can interact.

The Vee heuristic technique was designed by Gowin [19] as a strategy to solve a problem or to understand a procedure and could be applied both in primary and secondary education and in the university. Vee diagram was proposed by Gowin, as a tool to be used to critically analyze research, understand an experiment in the laboratory, as a teaching method for promoting meaningful learning and elicit knowledge. According to Guardian and Ballester [20], Gowin's Vee is a heuristic and metacognitive technique that illustrates and facilitates learning through theoretical and methodological elements that interact in the process of building knowledge for solving a problem. Therefore, the Vee is considered a technique used to learn to learn (and think). This is a diagram in a V, which is represented visually as a knowledge structure. Knowledge refers to objects and events in the world. We learn something about it when posing questions under concepts organized into sets of principles (which explain how objects and phenomena behave) and theories, from which we can plan actions (experiments) that will lead us to answer the initial question. Novak [27] showed that CCMM and Vee diagrams positively influence teaching, learning, curriculum and environment, and these four elements, along with the feelings and actions, become part of any meaningful educational experience. The Vee diagram was designed as a heuristic tool that interrelates the knowledge, know-how and knowledge to be; for example, the contents related to concepts, procedures and attitudes (scientific competences); and also allows integrating everyday knowledge with scientific knowledge, being considered highly significant. (Ausubel et al. [3]; Novak and Gowin [29]; Barriga and Hernandez [4]; Sánchez [38]; Ontoria [34]). Authors such as Anta [1] have conducted research related to the usefulness of the schemes and specifically of Vee diagrams in different disciplines, educational levels and national and international academic spaces. All agree on the usefulness of this tool for the meta-cognitive development of students.

Gowin [19] posed five original questions to apply to any statement or document in which some knowledge is present:

(i) Which is the decisive question?

(ii) Which are the key concepts?

(iii) Which the research methods are used?

(iv) Which are the main statements about knowledge?

(v) Which are the main value judgments?

These five questions summarize the construction of knowledge, for understanding to solve the posed problem. The model has been adapted to different sciences and areas of knowledge for its effect on the production of meaningful learning. One of the most important models was applied by Moreira [26] in Brasil, with considerable success. In some of his articles, he shows the application of the Vee, especially in problem solving activities in secondary and university education. Moreira [26] stated meaningful learning is a process through which the same information relates, in a non-arbitrary and substantive manner, with an important aspect of the cognitive structure of the individual. Thus, meaningful learning is characterized by interaction, and not a simple association between specific and relevant aspects of the cognitive structure and new information. Meaningful learning involves questioning and requires the personal involvement of the learner; this is, according to Moreira [24], a reflexive attitude towards the process itself and the content learning object, tending to ask ourselves what we want to learn, why and why we want to do it in a meaningful way. Thus it arises a new contribution, which is its criticality. Moreira [25] considers that through critical meaningful learning it is how students can be part of their culture and at the same time not be subjugated by it, by its rites, myths and ideologies.

Also for Gowin [19], meaningful learning takes into account the important influence of emotional experience in the process leading to its development. It is not just a result, but a process in which meanings are shared; this idea is widely developed in the postulated educational theory. He considers, "teaching is consumed, when the meaning of the instructional material the student grasps, becomes the meaning that the teacher intended that this material should have for the student". Rodríguez et al. [38] mention that the essential contribution of Gowin, is the establishment of a triadic interaction between teacher/student/ educational curriculum materials aimed at sharing meanings, without which, in any way, meaningful learning would not be 
obtained. In addition, Gowin defines the responsibilities of the different actors in the process of learning; for example, the educational curriculum materials, should follow some pedagogical and didactic orientations (Zufiaurre and Belletich, [42]; Belletich and Pérez de Villarreal [5]; Pérez de Villarreal and Zufiaurre, [36]), which show the importance of the design and programming of educational processes, clearly explained in the Instructional Design Theory, considering particularly important the design approach in science education. According to Godino et al. [12], the learning research based in design (design research or design of experiments) is part of a family of methodological approaches, which takes place in the natural context of a class. It uses systematical design, analysis tools and instructional strategies. Thus, the research includes, in successive cycles, both the design and implementation in the context of a class and the evaluation of the results. In this theory, three main elements may be considered in all the teaching sequence: planning (programming), execution (activities) and assessment (acquisition of skills or competencies). Also, other research studies carried out by González [15]; González et al. [17]; Novak [31] show wide evidence, demonstrating the great potential of CCMM to improve teaching, both for the diagnosis of students' prior knowledge and for the design and implementation of consistent curriculum and instruction by the teacher. The three components of the Instructional Design Theory should be included, all under the perspective of the objectives: Programming (prior organization of the number of weeks provided for theoretical instruction and the number of weeks aimed at practical sessions in the spring semester); Execution (activities to develop: initial, processing and summary); Assessment (skills developed in each activity).

Our present work, aimed at enhancing the use of this methodology in our students, as future teachers in primary education, so that the chain of meaningful learning by the use of metacognitive tools should start rolling. For that, we considered we should teach the subject of TNS by using this methodology, in a consistent and coherent manner with what they should use as teachers. In this case, we changed the presentation of the contents of the subject TNS which corresponds to the second semester of the second year of the BDPE at the Public University of Navarra (Spain), by creating a Knowledge Model.

\section{Material and Methodology}

STEM education is based on the idea of educating students in four specific disciplines, such as science, technology, engineering and mathematics, in an interdisciplinary and applied approach. However, fewer and fewer students have been focusing on these topics recently, which means their interest is worryingly decreasing. The reasons could be in the way of teaching
STEM subjects, as separate and discrete subjects, instead of integrating them into a cohesive and meaningful learning paradigm based on real world applications, such as the development of integrated Knowledge Models (KM).

\subsection{Design of the Subject TNS}

In this study, we aimed to implement a new system of subject presentation forwarded to students of the BDPE, who, in turn, will be responsible for educating generations of children in STEM subjects. In order to introduce the appropriate changes in the education system, it is important to start from primary education, when students are very young, continue in middle school and finish in high school. This should be the network that will encourage the use of knowledge models to teach STEM subjects. The subject "Teaching Natural Sciences" (TNS), belongs to a broader subject "Teaching Experimental Sciences" and is specifically linked to the field of "Knowledge of natural and social environment". It is compulsory in the curriculum of the Public University of Navarra, and consists of a total of 6 ECTS (European Credit Transfer System) from a total of 24 ECTS (in the whole subject).

It develops the following topics:

- Teaching and learning sciences today.

- Science and modeling.

- Physical systems.

- Matter and its changes.

- Living things and their environment.

- The human body.

- School scientific activity: key ideas, curriculum, previous ideas of students and media for their evolution.

- Resources for teaching Studies: field trips, ICT and laboratory.

- Fundamentals and the application of the scientific method in teaching and learning about the natural environment.

- Theory to design environmental exploration projects.

- Inquiry learning.

- Guidelines for preparing proposals and integrated educational projects based on the Natural Environment which are called Instructional Modules (IM).

The subject TNS was developed according to the Curriculum of Primary Education in Navarra (Spain) and aims to expand and deepen the content and necessary skills to teach the subject "Natural Environmental Knowledge" (NEK), which is compulsory in the three cycles (each cycle comprises two courses) of Primary Education involving students from 6 to 12 years old. In TNS, students work specially on scientific ideas they will develop in NEK in Primary Education ("content of school science"), and how to approach the learning and teaching process (LTP) by 
promoting constructive and inquiry activities. Some of these activities integrate the use of Information Communication and Technology (ICT) Tools, such as Cmap Tools software (IHMC, Institute for Human Machine and Cognition, Florida, USA) for their use in the social construction of knowledge.

\subsection{Objectives of TNS}

The aim of this work was to check if the presentation of the subject TNS as a KM (including interlinked CCMM with different levels of deepness of the developed natural science topics) has a positive effect in the learning/ teaching process of the students attending class.

For that, it is necessary to bear in mind the specific objectives of the subject TNS, which are:

- To identify and discuss the contents of basic school science and the key ideas developed in Primary Education.

- $\quad$ To deepen the perspective of teaching and learning in school science activities those integrate construction, inquiry, research and communication.

- To know, propose and evaluate activities for the development of scientific competence in Primary Education.

\subsection{Skills}

The skills students have to demonstrate to have acquired at the end of the academic year are the following:

\section{Basic skills (BS):}

BS1 - That the students have demonstrated knowledge and understanding in a field of study that part of the basis of general secondary education, and is typically at a level which, although it is supported by advanced textbooks, includes some aspects involving knowledge of the forefront of their field of study.

BS2 - That the students can apply their knowledge to their work or vocation in a professional manner and have competences typically demonstrated through devising and defending arguments and solving problems within their field of study.

BS3 - That students have the ability to gather and interpret relevant data (usually within their field of study) to inform judgments that include reflection on relevant social, scientific or ethical issues.

BS5 - Those students have developed those skills needed to undertake further studies with a high degree of autonomy.

\section{General skills (GS):}

GS1 - To know the curricular areas of Primary Education, the interdisciplinary relationship between them, the evaluation criteria and the body of didactic knowledge regarding the respective teaching procedures and learning.

GS2 - To design, plan and evaluate teaching and learning processes, both individually and in collaboration with other teachers and school professionals.

GS7 - To collaborate with different sectors of the educational community and the social environment, assuming the educational dimension of the teaching profession and promoting democratic education for active citizenship.

GS8 - To maintain a critical and autonomous relationship with respect to knowledge, values and public and private social institutions.

GS9 - To assess individual and collective responsibility in achieving a sustainable future.

GS10 - To reflect on classroom practices, to innovate and improve teaching, acquiring habits and skills for independent and cooperative learning and promoting it among students.

GS12 - To understand the role, possibilities and limits of education in today's society and the core competencies affecting Primary Education schools and its professionals. To get to know models of quality improvement with application to schools.

\section{Transversal competences (TC):}

TC2 - To demonstrate proficiency in Spanish and, where appropriate, in Basque equivalent to level $\mathrm{C} 1$ of the "Common European Framework of Reference for Languages: learning, teaching, assessment" of the Council of Europe.

\section{Specific competences (SC):}

SC1 - To know the objectives, curriculum content, the meaning of the areas and the organization, methodology and criteria for the assessment in Primary Education.

SC2 - To design, plan and evaluate teaching and learning in response to interdisciplinary and disciplinary criteria with other professionals.

SC7 - To promote cooperation, motivation and desire to learn, and actively participate in school projects.

SC9 - To acquire habits and skills for autonomous and cooperative learning to promote the active involvement of students in their social and personal development.

SC10 - To reflect regarding classroom practices to innovate and improve teaching, and refer to the operation of the basic psychological processes, pedagogical models and disciplinary criteria of the stage.

SC12 - To actively organize the teaching and learning of the contents of Primary Education from the perspective of skills development. To get to know models of improvement quality.

SC14 - To contextualize the teaching action in the political, social, and pedagogical changes, fostering democratic education and development of active citizenship for achieving a sustainable future.

\subsection{The Structure of TNS in the Teaching Guide of the Public University of Navarra}

This subject consists of 6 ECTS which correspond to 
150 hours/ work for the student; of them, $40 \%$ (60 hours) belong to classroom and lab teaching (with theoretical and practical sessions) and $60 \%$ (90 hours), to personal study. TNS caters to the teaching sequence consisting of: Programming, Implementation and Evaluation.

\subsubsection{Programming and Organization}

The number of hours aimed at teaching, are spread over 15 weeks, leaving the last week for working on the IM, in which the students (in groups of 4-5) have to develop a selected topic contained in any of the 5 blocks of the area of Natural Sciences, inside the Curriculum of Primary Education in Navarra showed in BON [7] and defend it orally during 15 minutes.

\subsubsection{Implementation}

- Structure of the theoretical and practical content:

The agenda is structured in three blocks, taking into account the philosophy (cognitive / constructivist) underlying the approach of the subject. Firstly, Block I was designed to lay the theoretical foundations that allow students to learn meaningfully and build knowledge (through research related processes), to provide them with the appropriate tools to carry out these tasks. Also, in Block II, it is intended that the students learn the curriculum of primary education, with regard to Environmental Awareness. In Block III, all theoretical and practical knowledge acquired in Block I, is used for the development of the IM based on a selected block of the Natural Science curriculum, evidencing the knowledge acquired by the students and their domain, which is shown through public presentation of the Knowledge Model.

\section{BLOCK I:}

\section{Item 1: Analysis of educational models: traditional (behaviorist, positivist) and progressive (cognitive and constructivist)}

1.1. Theories for teaching / learning Science: Ausubel, Novak and Gowin.

1.2. Fundamental principles thereof

1.3. Theory of Misconceptions

\section{Item 2: Instructional Techniques for improving the learning-teaching environment}

2.1. CCMM and meaningful learning of the natural environment

2.2. The Vee diagram knowledge, meaningful learning environment, building knowledge and research process of the natural environment

\section{BLOCK II:}

\section{Item 3: Curriculum of Primary Education in Navarra} (Spain). Science: objectives, content and evaluation criteria
3.1. Learn about physical systems in primary education. What are the key ideas? What does the curriculum say? What previous ideas do students have? How can we evolve?

3.2. Learning about matter and its changes in primary education. What are the key ideas? What does the curriculum say? What previous ideas have the student? How can we evolve?

3.3. Learn about living things and their environment in primary education. What are the key ideas? What does the curriculum say? What are the previous ideas students have? How can we evolve?

3.4. Learn about the human body in Primary Education. What are the key ideas? What does the curriculum say? What are the previous ideas students have? How can we evolve?

\section{BLOCK III:}

\section{Item 4: Development of a curriculum and instructional design regarding selected aspects of Experimental Sciences}

4.1. Guidelines for the development of a curriculum and instructional design in relation to the Natural Environment

4.2. Developing the corresponding knowledge

4.3. Public presentation of the Instructional Module (IM)

- $\quad$ The teaching methods used are:

- Masterly exhibition (purely theoretical content) in large group (44 students). In these sessions, the teacher raises previous ideas concerning the particular issue to address in order to detect students' prior knowledge; then, she leaves a time (about 15 minutes) for students to comment and discuss between them. After this time, they put in common and the teacher comments the CCMM or presentations referred to the particular issue, in order to solve any questions that will arise students, avoid misconceptions and at the same time, refresh prior knowledge.

- Practical and laboratory exercises in medium groups (24 students in one medium group and 20 in the other). For the development of the practical training, students are gathered in small groups of 4-6 individuals, which are held throughout the semester, managing themselves and distributing the work to be done. In these sessions, students perform practical exercises related to theoretical contents, or where appropriate, develop laboratory experiments, perform dramatizations, write reflections on the research method or methodologies, read research articles, play trivial based on TNS contents, and finally publicly expose their Instructional Module (IM).

- Face tutorials: they are designed to answer questions and establish guidelines and tasks for self-study. 


\subsubsection{Assessment}

Table 1. Table showing TNS Assessment

\begin{tabular}{|c|c|c|}
\hline ASSESSMENT & \% OF VALUE & \% RETRIEVABLE \\
\hline Assistance and participation & 10 & 15 \\
\hline Theoretical work, practical activities, reviews, synthesis & 20 & 15 \\
\hline Instructional Module (containing Knowledge model) & 30 & 40 \\
\hline Oral or written tests & 40 & 70 \\
\hline TOTAL & 100 & 0 \\
\hline
\end{tabular}

\subsection{Vee Diagram}

In order to clarify the structure and design of TNS subject, and following Gowin's study [19], a Vee diagram was developed so that teachers could follow the steps to perform the Knowledge Model and it could also serve as a guide for obtaining the initial goals, derived from the focus questions related to the specific objectives of the subject (see 2.1).

\begin{tabular}{|c|c|c|}
\hline CONCEPTUAL & & METHODOLOGICAL \\
\hline $\begin{array}{l}\text { WORLDVIEW } \\
\text { Through meaningful learning and the development of } \\
\text { Knowledge models in the course TNS, students learn how to } \\
\text { teach in Primary Education in order to develop a critical spirit } \\
\text { and to avoid misconceptions. } \\
\text { FILOSOPHY } \\
\text { - Constructivism.: It is based on the construction of meaning ful } \\
\text { learning actively to get to knowledge. } \\
\text { - Environmental: it tries to prepare students to act as responsible } \\
\text { and take part on environmental problems arousing certain } \\
\text { attitudes that lead to it. } \\
\text { THEORIES } \\
\text { 1. Constructivist: Ausubel, Novak, Gowin. } \\
2 . \text { Meaningful learning } \\
3 . \text { Biology, Geology, Physical and Chemical Science. } \\
\text { PRINCIPLES } \\
\text { - Meaning ful learning occurs when new information acquires } \\
\text { meaning for the individual through the relationship with prior } \\
\text { knowledge. Therefore, we teach them from their interests. } \\
\text { - Nature is an important educational resource. } \\
\text {-Understanding and assessing the environment in which we live } \\
\text { can help us to actively participate in its care and protection. } \\
\text { - It is important to get to know contents on Biological, geological, } \\
\text { physical and chemical science to be able to explain them to } \\
\text { Primary Education students.e } \\
\text { CONCEPTS } \\
\text { (1) Meaningful learning, previous knowledge, students' } \\
\text { interests, concept map. } \\
\text { (2) Environmental education. } \\
\text { (3) Biology, Chemistry, Geology, Physics. }\end{array}$ & $\begin{array}{l}\text { Will students from "Teaching Natural Sciences" (TNS) course } \\
\text { acquire all the competences by developing the Knowledge Model } \\
\text { created by the University teacher? } \\
\text { Will they understand the consistency of teaching them in the } \\
\text { system they will have to implement in order to learn how to } \\
\text { teach? } \\
\text { Will they appear motivated and committed to quality educazion } \\
\text { and adapt to the time in which they live? } \\
\text { Will they apply Knowledge models in their future teaghing in } \\
\text { Primary Education? }\end{array}$ & $\begin{array}{l}\text { VALUE JUDGEMENTS } \\
\text { We consider the developed Knowledge Model, as highly } \\
\text { valuable and appropriate for getting meaning ful learning and } \\
\text { for acquiring the competences needed to become Primary } \\
\text { Education Teacher. } \\
\text { We believe this work is a valuable tool for all those involved } \\
\text { in education: parents, teachers, students and officials of the } \\
\text { Department of Education and Culture. } \\
\text { KNOWLEDGE JUDGMENTS } \\
\text { Students will acquire all the competences from TNS by } \\
\text { developing the Knowledge Model created by the teacher. } \\
\text { They will understand the consistency of being taught in the } \\
\text { way they will have to teach in the near future. } \\
\text { They will appear motivated and committed to improving } \\
\text { quality education and adapting to the time they live. } \\
\text { They will apply Knowledge models in their future teaching } \\
\text { activities. } \\
\text { TRANSFORMATIONS } \\
\text { - Power Points, concept maps, scientific publications. } \\
\text { REGISTRIES } \\
\text { - Registration of the prior and new knowledge acquired } \\
\text { through the instructional module. } \\
\text { - Observed data from the various activities } \\
\text { - Concept maps. }\end{array}$ \\
\hline
\end{tabular}

Figure 1. Vee diagram of the subject TNS with the focus questions highlighting the objectives of the work.

As mentioned in the introduction, Gowin [19] developed this heuristic tool which incorporates 12 elements for the process of knowledge construction, including not only the steps of the scientific method, but also the conceptual knowledge represented on the left of the Vee, including the world view, philosophy, theories, principles and concepts, guiding the research. For González [15], the Vee diagram is a method which can help students and educators to analyze the structure and meaning of the knowledge they try to understand (metacognition) and allows the incorporation of new knowledge to the cognitive structure the student already has transforming the learning process into a meaningful one. The shape of "V", is not an accident, but it was designed to house on the left side the conceptual / theoretical (thinking) part, and on the right side, the methodological / practical (doing) part, both directed to refer to objects and events in the process of knowledge production.

The Vee diagram (Figure 1) has been designed in order to answer the following focus questions which point to the objectives of this work and represent a guide for the teacher throughout the whole learning/teaching process (LTP).

- Will students attending the subject "Teaching Natural Sciences" (TNS) acquire all the competences for becoming Primary Education Science Teachers, by developing the Knowledge Model created by the University teacher? 
- Will they understand the consistency of teaching them in the system they will have to implement as future teachers (constructivism), in order to learn how to teach and avoid the positivist or behaviorist didactic style in which they were taught?

- Will they appear motivated and committed to quality education and continue their "long life training", adapting to the time in which they live and leaving the comfort zone of repeating merely transmissive models and rote mechanical learning?

- Will they apply Instructional Modules (IM), which contain Knowledge Models (KM), in their future, for creating their own teaching material conceptually transparent when becoming Primary Education Teachers?

This heuristic and metacognitive tool is recommended to be used by teachers of the Elementary School for designing the LTP (learning/teaching process), but it can also be used in Middle and High School by students for improving laboratory, field and studio instruction [29] and for analyzing original materials, especially in subjects STEM related.

\subsection{Inquiry}

As an instrument to measure students' perception, an inquiry was designed to check the usefulness of the new presentation of the subject TNS (as a Knowledge Model using Cmap Tools software) and if it helped to answer the focus questions of the Vee diagram. These questions are really the goal of this work and encourage a new way of teaching STEM subjects through the development of KM in BDPE students, who will be the ones responsible of adapting this new system when teaching STEM subjects. This survey was answered anonymously by the students attending class (30 students) the day before they defended their IM.

\section{Results}

In this proposal, we show the different CCMM which belong to the KM developed by TNS teachers, as an example of what can be done by students to learn STEM related subjects or to develop their own teaching material as future teachers. This teaching strategy aided by the Cmap Tools software is a valid and original teaching strategy for STEM subjects and may be exported to other subjects and research areas. The final goal of this teaching strategy is that students should be encouraged to design their own KM and master their own acquired knowledge.

\subsection{Development of a Knowledge Model (KM), Using as Example the One Designed by the Teacher for Explaining TNS Subject.}

Novak and Gowin [29] defined CCMM as diagrams which indicate the relationships among key concepts or nouns and it is a technique proposed and developed by Joseph Novak. The relationships are shown by linking words which are normally verbs, adverbs or prepositions that make a whole sense to the sentence created when linking concepts, which is called proposition. CCMM are powerful tools for describing structures of disciplinary knowledge through conceptual hierarchies or meanings, from general to more specific rules and they are dynamic creatures which evolve together with the knowledge of the student. It represents clearly, the cognitive structure of an individual, as if it were a mirror; so it means, it is different for each student. Graphic icons linked to concepts of the CCMM can be displayed by clicking on them and then on the writing that appears. Information shall be so displayed in the interface. The original map with the associated resources can be accessed downloading the free software Cmap Tools, of the Institute for Human and Machine Cognition as explained in a previous study of Novak and Cañas [30]). The combination of subordinated CCMM linked among them and containing resources conform the $\mathrm{KM}$, and clicking on the links, the user is able to navigate through the whole model. According to authors like Novak and Cañas [2006] and González [15], the elaboration of KMs is a useful tool to create meaningful learning and avoid conceptual misconceptions.

In general, a KM consists of a set of CCMM and digitized resources associated therewith, all in relation to a particular topic, in our case, related to TNS subject. It can also be defined as a collection of CCMM linked to a root map representing increasing levels of specific differentiation. Where appropriate, associated resources (photos, documents, videos, etc.) are designated generically with graphical icons, are linked to the maps' concepts.

The power of this teaching strategy is to gather all the contents in one click and to be able to design the teaching material with creativity, originality and close to the "real world".

In the following figure, we show the root map of the KM designed to teach meaningfully the subject "Teaching Natural Science (TNS)". 


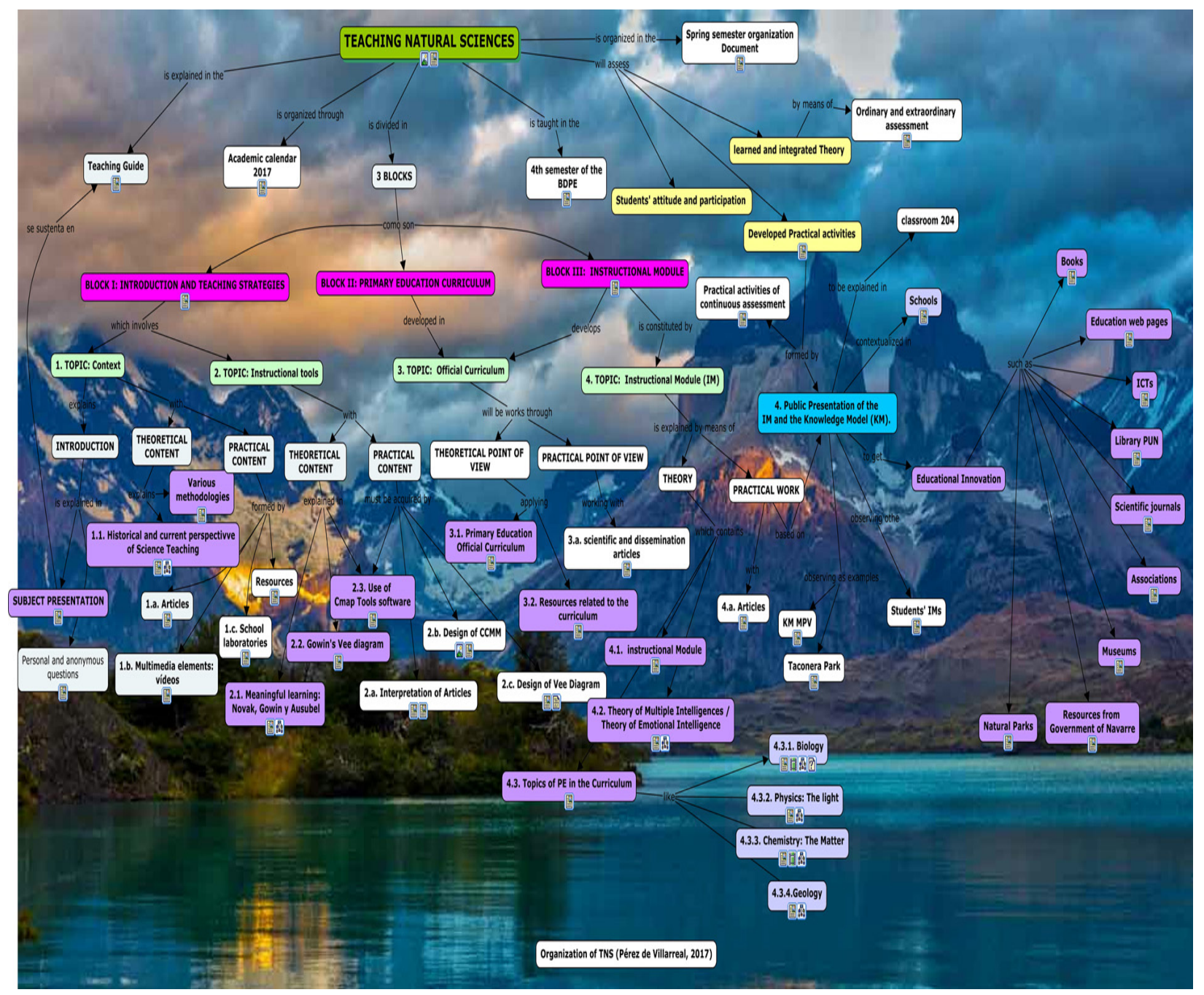

Figure 2. KM of the subject "Teaching Natural Science" which contains all the links and resources associated, students have access to. Available at: http://cmap.unavarra.es/rid=1S0VNH5FY-1CK7P20-45V/TNS\%20english.cmap

From this root map it is possible to have access to all the theoretical and practical content of TNS subject. The map is structured in the same way as the teaching guide, containing three blocks with the correspondent theoretical and practical content, and showing all the resources and subordinated maps associated. 


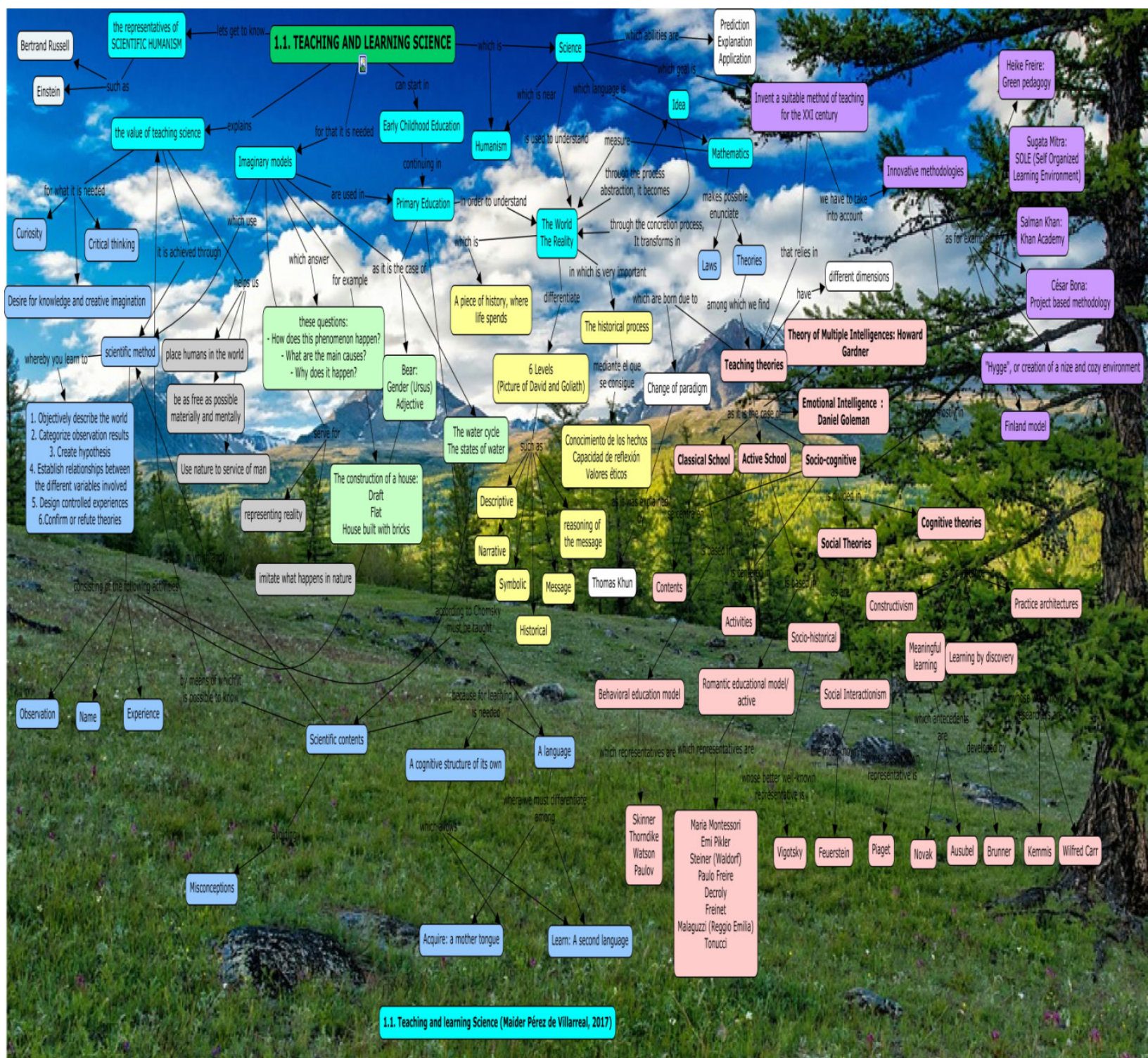

Figure 3. $\mathrm{CM}$ of the first theoretical topic of the first Block of "Teaching and Learning Science". Available at: http://cmap.unavarra.es/rid=1S0VQ6SHP-20RDFDF-C5X/1.1.\%20Teaching\%20and\%20Learning\%20Science.cmap

This is the first subordinated CM showing the theoretical content of the first topic of the first block "Teaching and Learning Science". In general it summarizes part of the theories underlying TNS and it contains videos and research articles as well. 


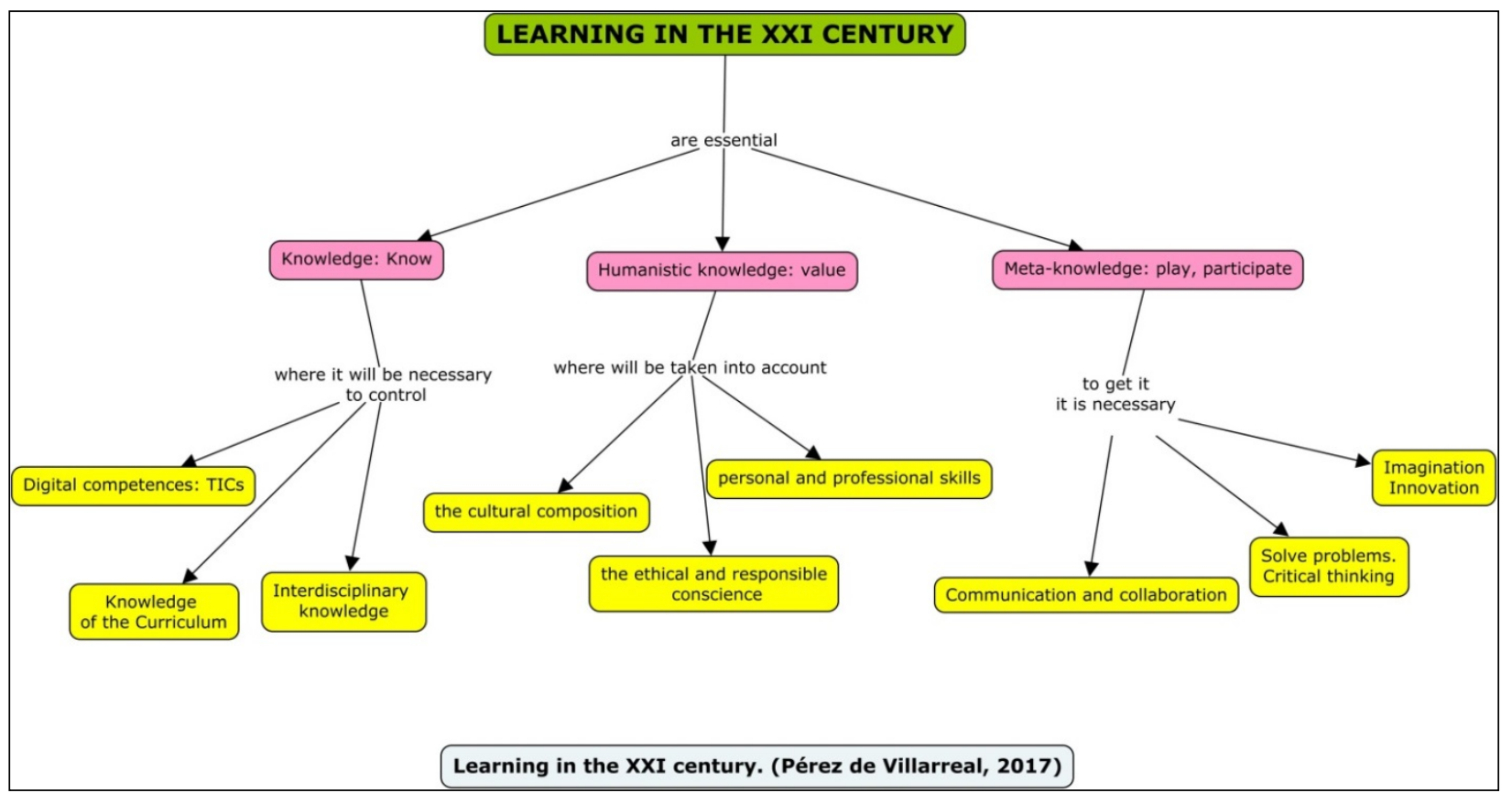

Figure 4. $\mathrm{CM}$ showing the essential characteristics for Learning in the XXI century. Available at: http://cmap.unavarra.es/rid=1S17QX835-N8PJF8-JK5/LEARNING\%20\%20IN\%20THE\%20XXI\%20CENTURY.cmap

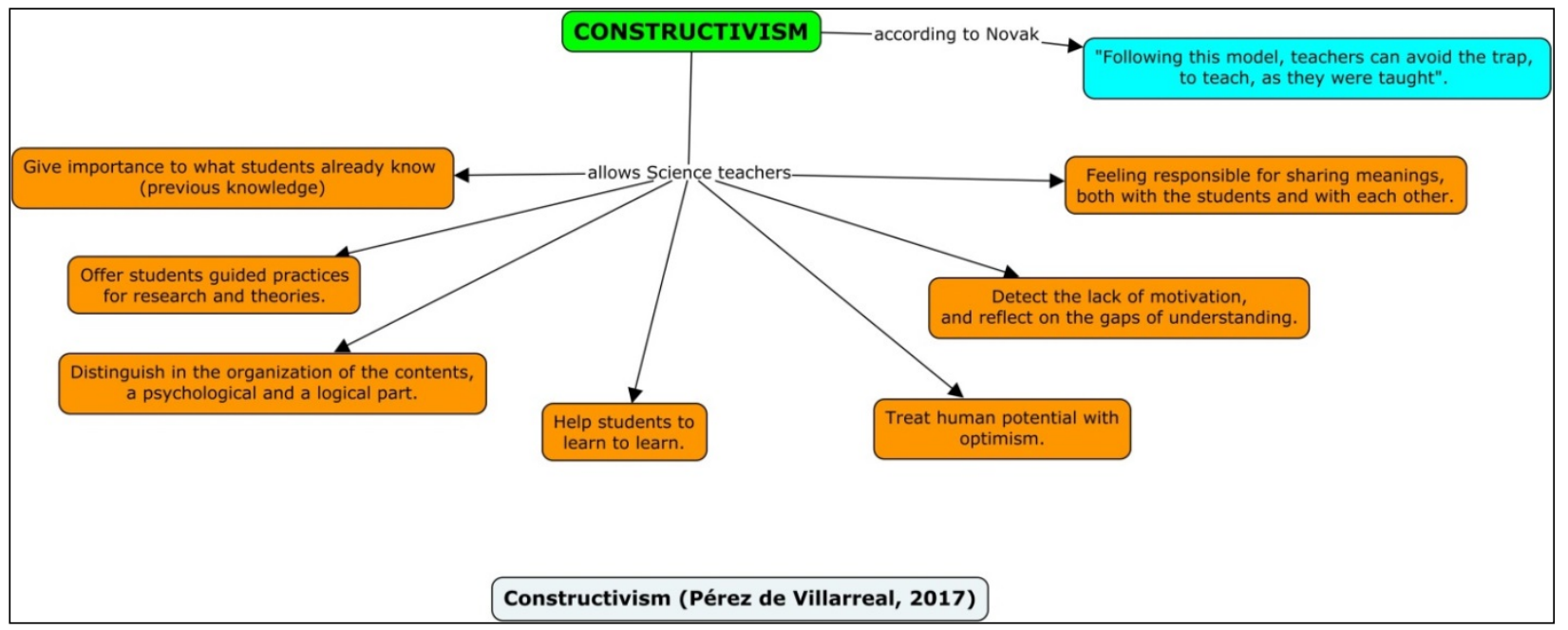

Figure 5. $\mathrm{CM}$ included in the second theoretical topic of the first Block, showing the characteristics of Constructivism. Available at: http://cmap.unavarra.es/rid=1S17PWWQB-29ST49B-C66/Constructivism.cmap 


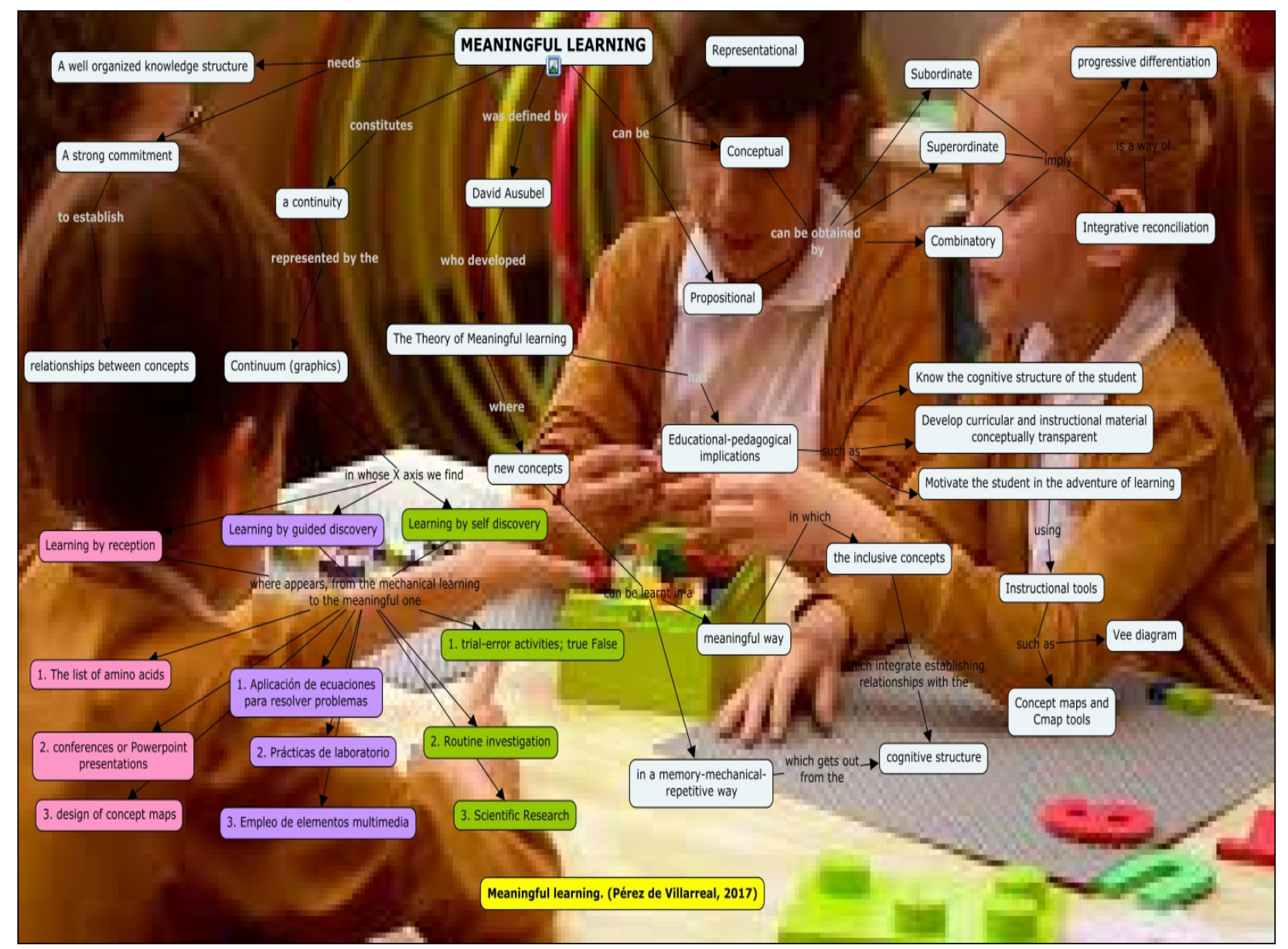

Figure 6. $\mathrm{CM}$ of the second theoretical topic of the first Block, "Instructional techniques", in which Meaningful learning is explained. Available at: http://cmap.unavarra.es/rid=1S10ZC4T8-15RX193-242/Meaningful\%20learning.cmap

In this CM, as explained by Posner et al. [37] the characteristics of the Conceptual Change needed for Meaningful learning are showed. 


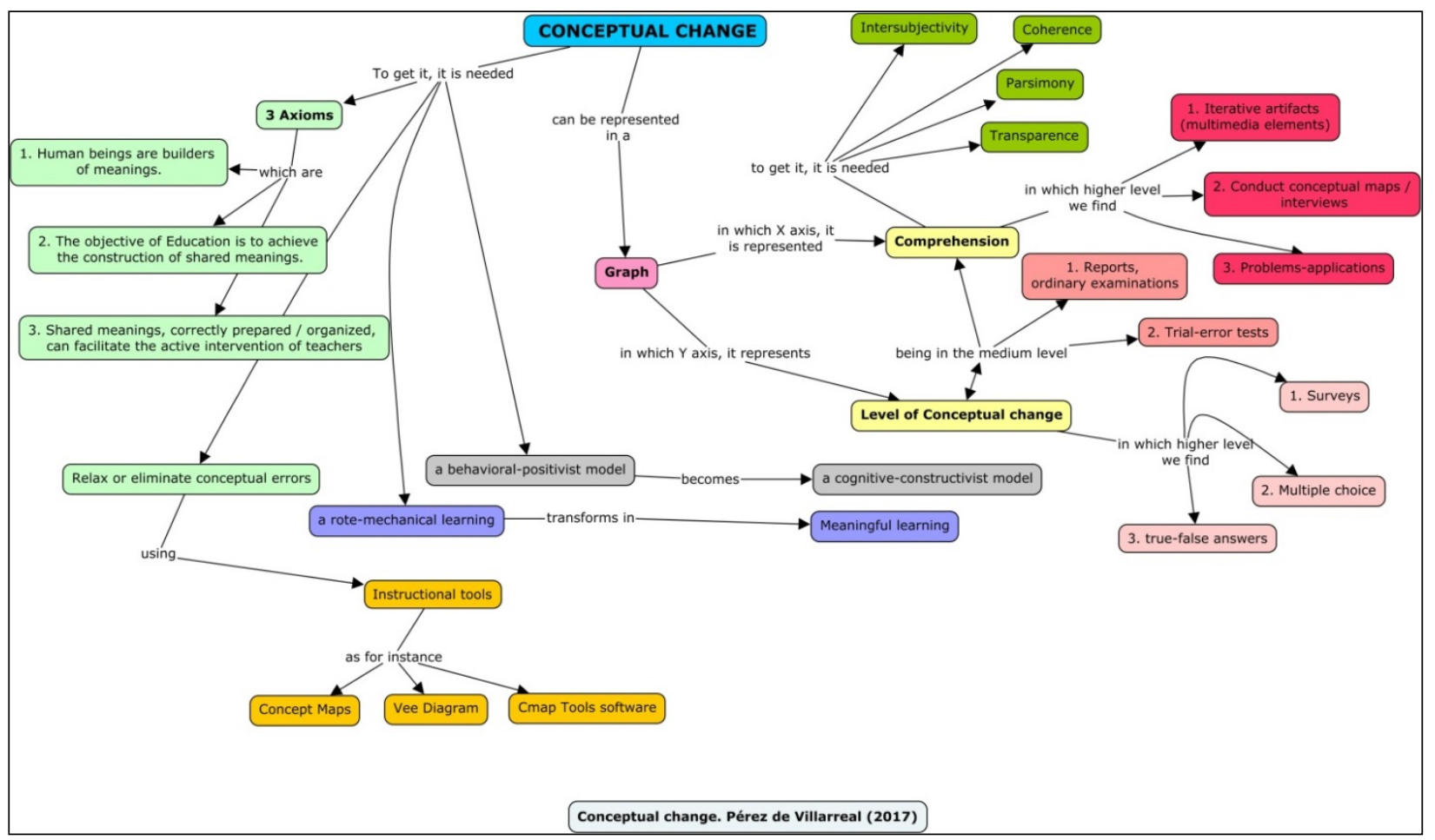

Figure 7. $\mathrm{CM}$ included in the second theoretical topic of the first Block, showing the axioms of Conceptual Change. Available at: http://cmap.unavarra.es/rid=1S17PG7KF-YSXNQX-BH8/Conceptual\%20change.cmap

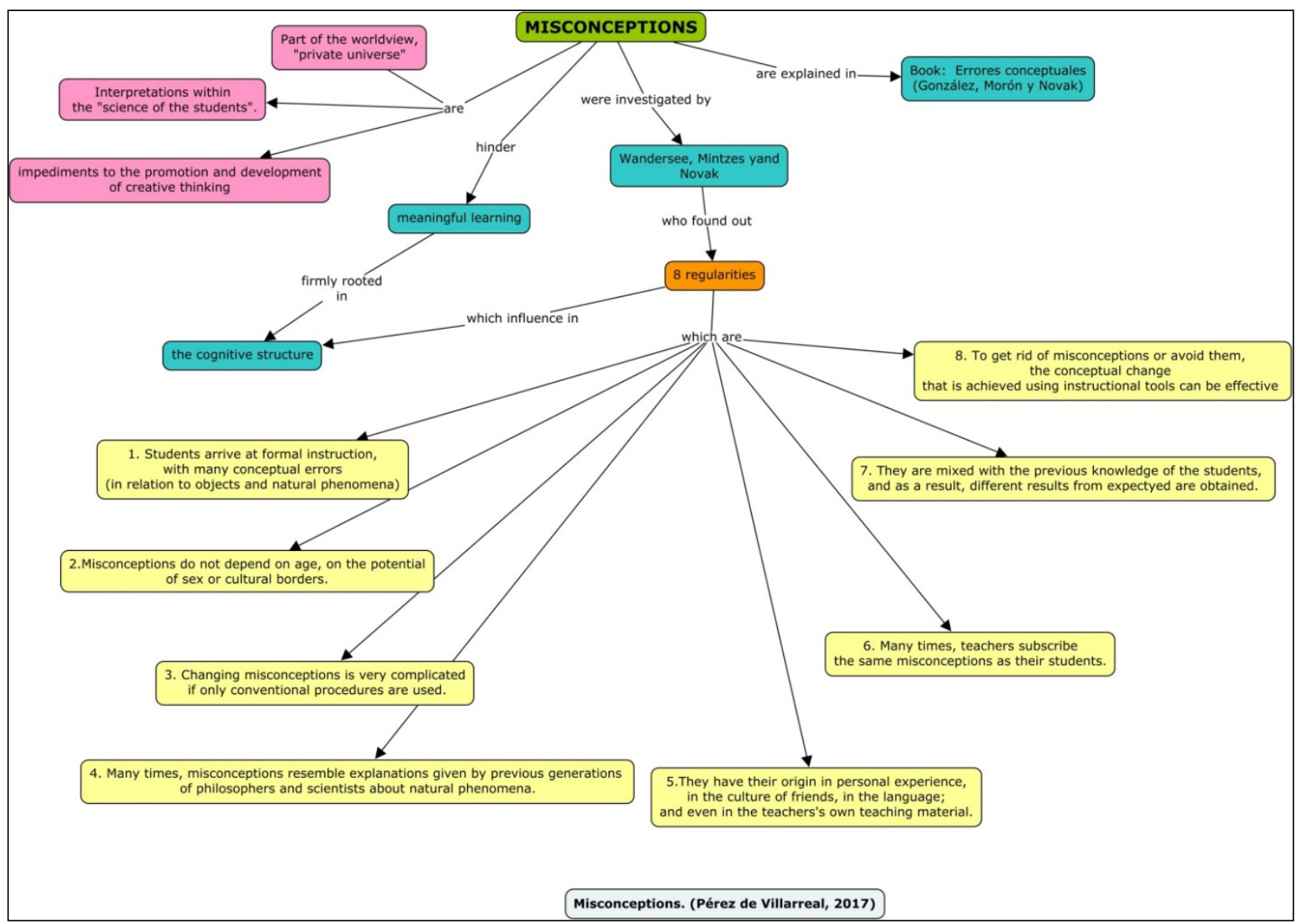

Figure 8. $\mathrm{CM}$ included in the second theoretical topic of the first Block, showing the 8 regularities perceived by Wandersee et al. [41] in relation to most misconceptions studied in the field of Science. Available at: http://cmap.unavarra.es/rid=1S17RHS0T-504F7J-KZP/Misconceptions.cmap 


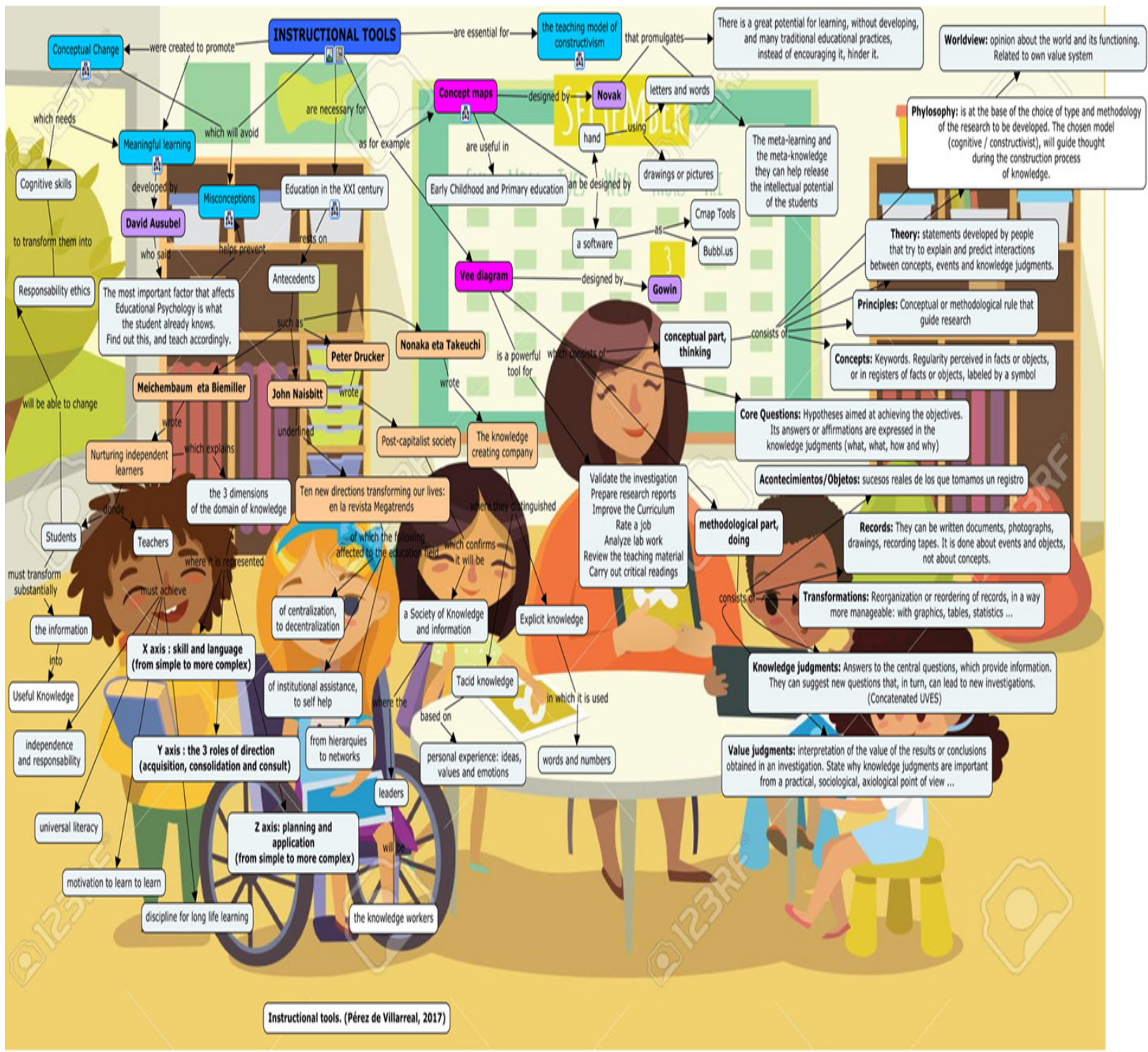

Figure 9. $\mathrm{CM}$ of the second theoretical topic of the first Block: "Instructional tools", which contains links to other subordinated concept maps.Available at: http://cmap.unavarra.es/rid=1S17X2FM2-1QWF2XX-3SF/Instructional\%20tools.cmap

By means of this CM, we show the usefulness of the heuristic tools in TNS subject. Not only Vee diagram is explained, but also, the design of concept maps for the preparation of transparent and substantial teaching material which can conform in the final instances, a Knowledge Model, such as an Instructional Module. 


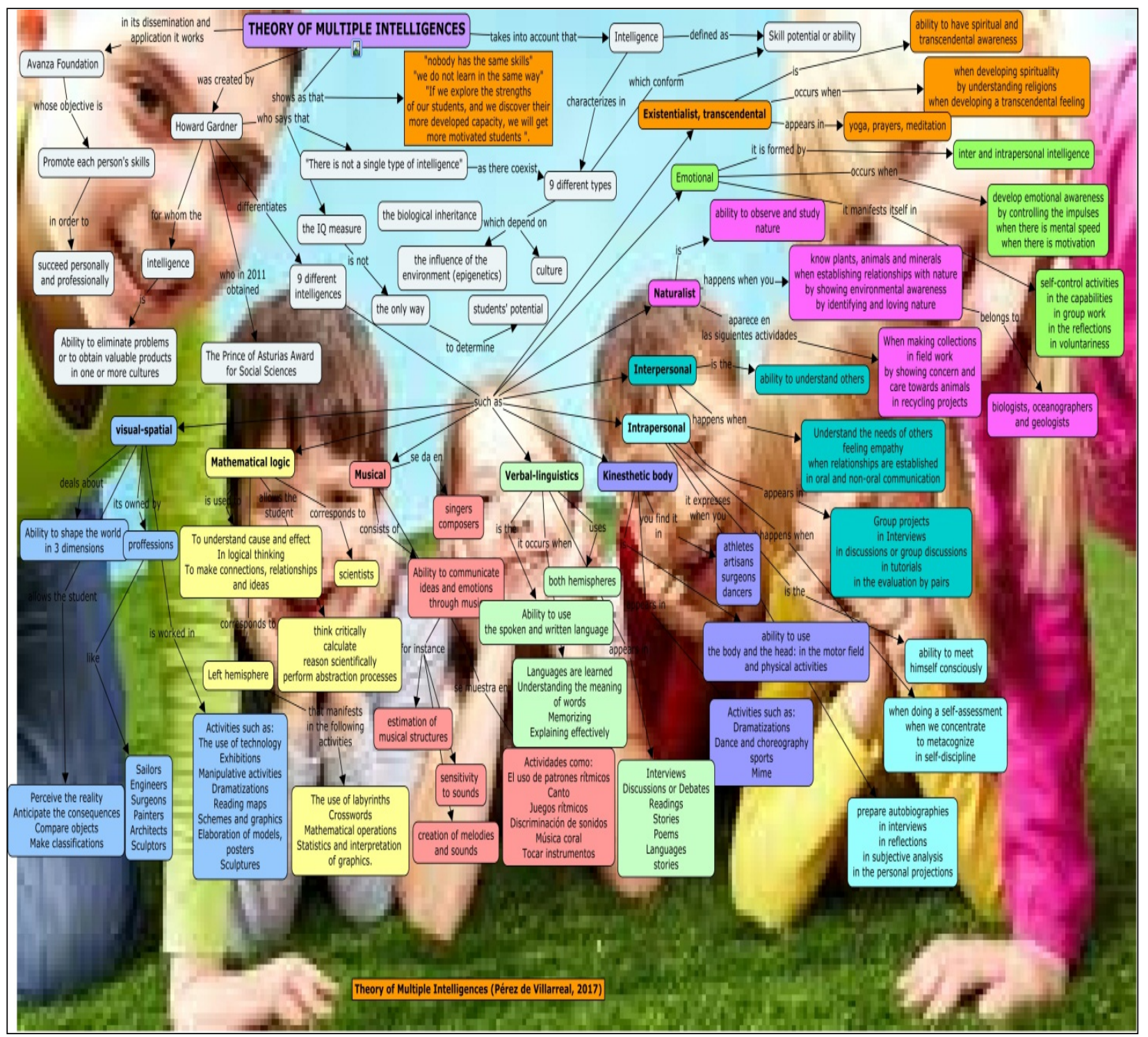

Figure 10. CM of a transversal theoretical topic related to the second Block: "Theory of Multiple Intelligences" to highlight the importance of developing teaching strategies taking into accounts the emotions, interests and abilities of students, even in science-related subjects. Available at: http://cmap.unavarra.es/rid=1S1JQGM0V-26VZS6P-CTS/Theory\%20of\%20multiple\%20intelligences.cmap

In both maps (Figure 10 and 11) both theories related to the abilities of human beings and to the consideration Intelligence is not only a matter of IQ (Intelligence Quotient) are showed; in the one side, the Theory of Multiple Intelligences developed by Howard Gardner [10], and in the other side, the Emotional Intelligence, by Daniel Goleman [13]. Both theories, although different, agree on the idea of the importance of managing emotions, not only for learning, but for personal and professional development of the individuals. 


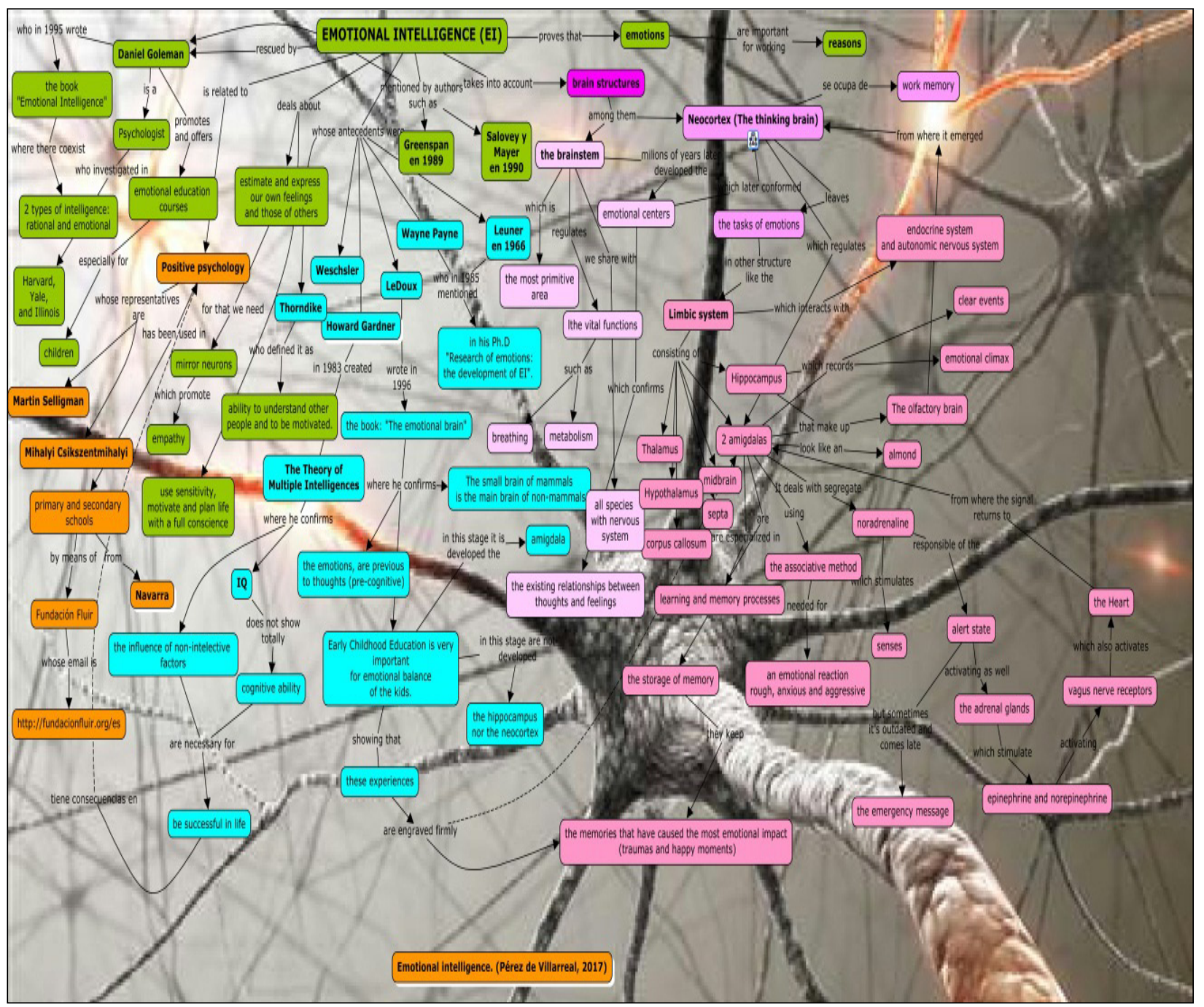

Figure 11. $\mathrm{CM}$ of a transversal theoretical topic related to the second Block: "Emotional Intelligence" inspired in Daniel Golemans's work and which also adds subordinated concept maps. Available at: http://cmap.unavarra.es/rid=1S180J5YH-RHXJ48-CTC/Emotional\%20Intelligence.cmap 


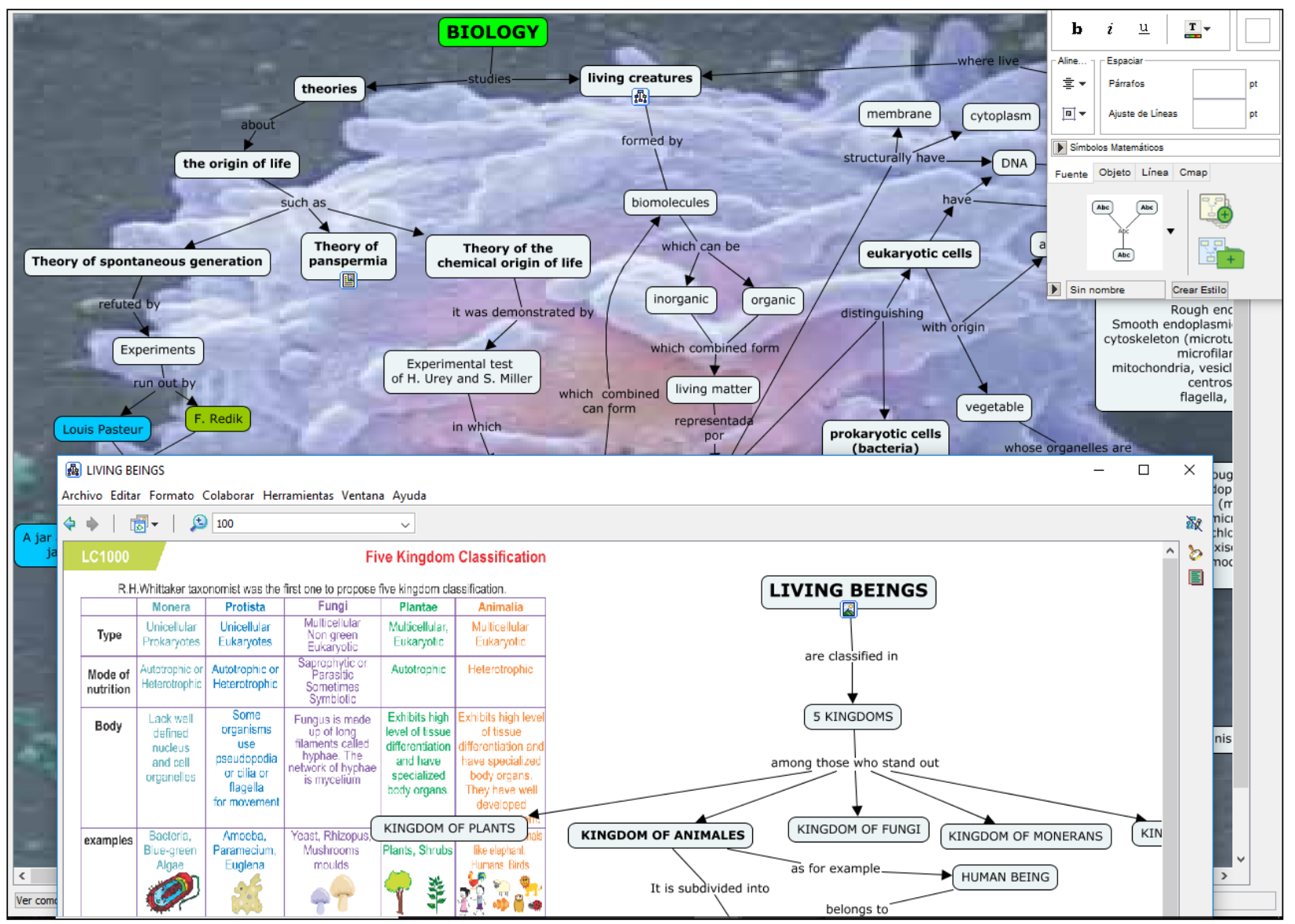

Figure 12. $\mathrm{CM}$ of the Biology contents to refresh previous ideas to TNS students with the "5 Kingdoms of the living beings" submap opened. Available at: http://cmap.unavarra.es/rid=1S1F8T13F-214C34M-2BW/BIOLOGY.cmap

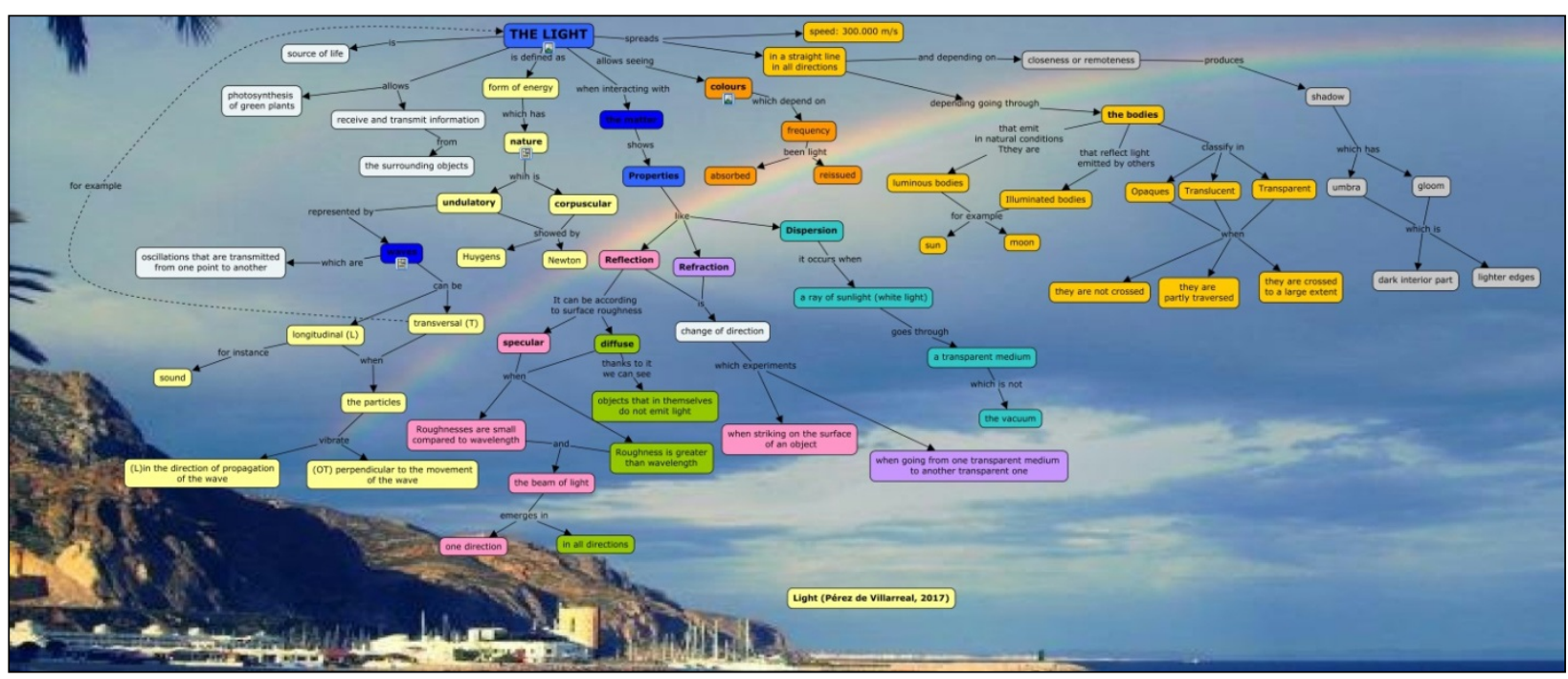

Figure 13. CM showing some of the Physics contents on the topic "The nature of light". Available at: http://cmap.unavarra.es/rid=1S1BQ5QZ2-97MTS-SJ6/THE\%20LIGHT.cmap 


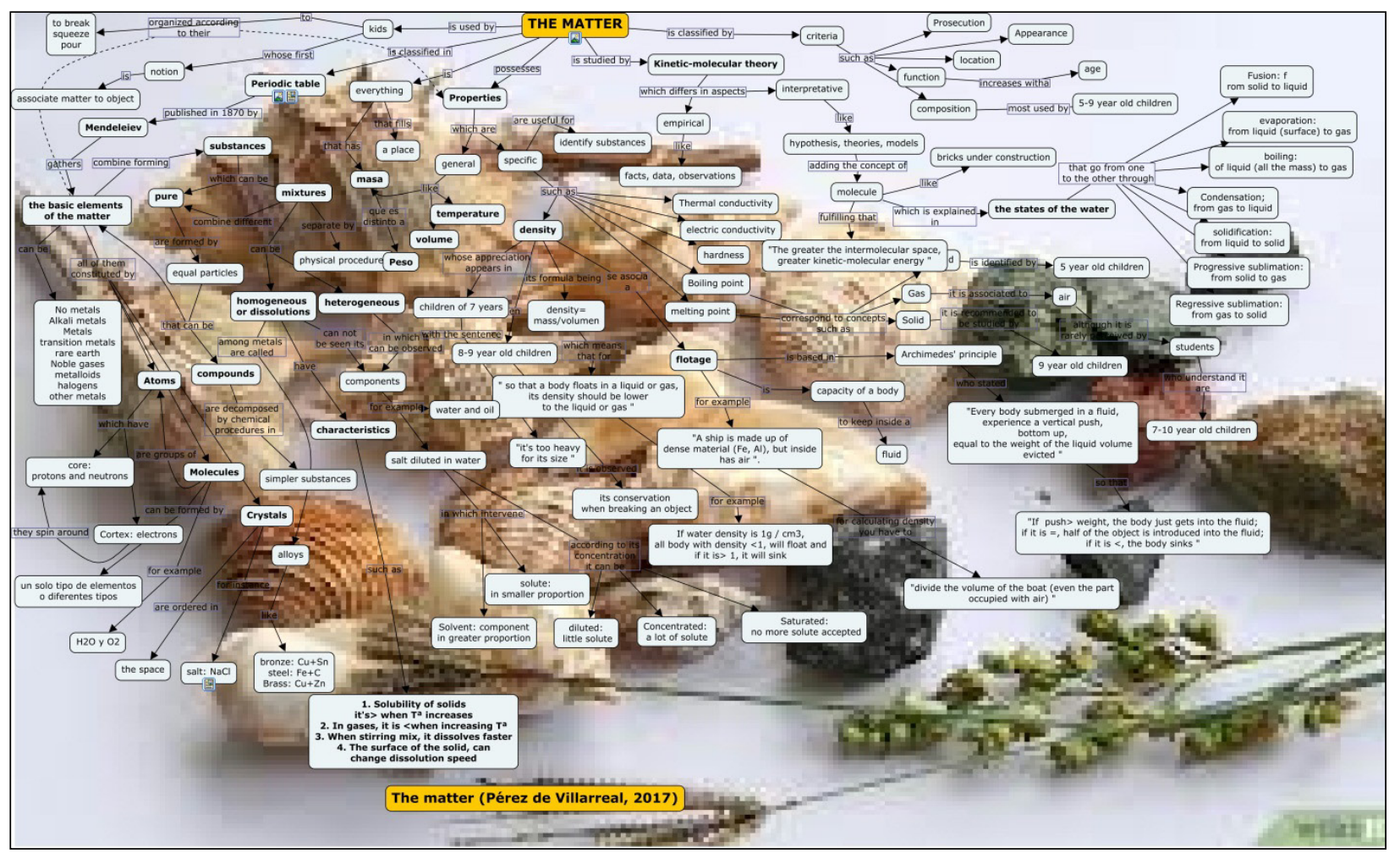

Figure 13. CM showing some Chemistry contents on the topic "The matter" used to refresh students' prior ideas and to avoid any misconceptions. Available at: http://cmap.unavarra.es/rid=1S1JSM3NX-1GFZTQG-HS5/MATTER.cmap

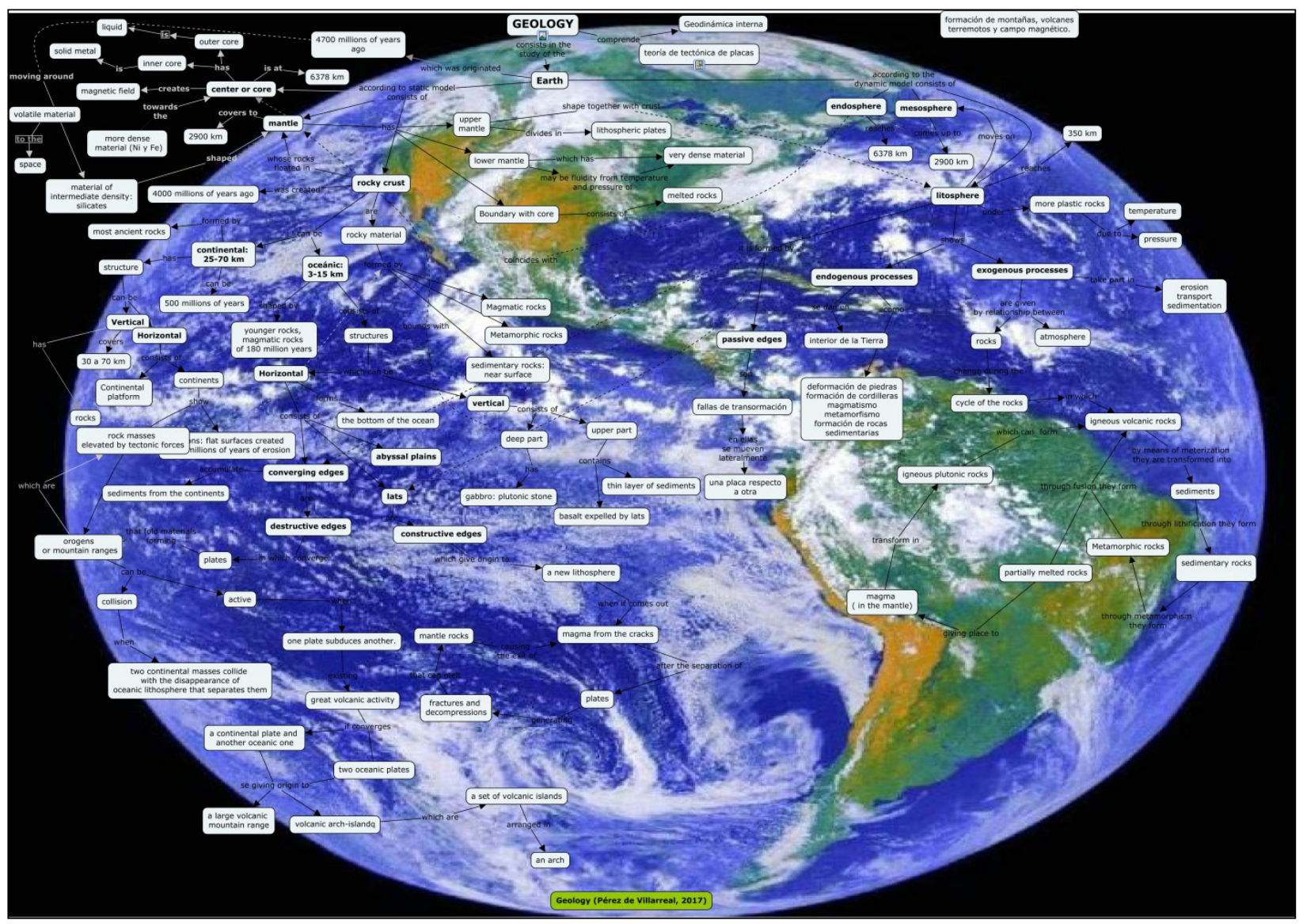

Figure 14. $\mathrm{CM}$ explaining the contents of the topic "Geology" designed for helping students' refresh their previous ideas. Available at: http://cmap.unavarra.es/rid=1S1BKRHBV-1TVHGWD-2Q7/GEOLOGY.cmap 


\subsection{Instructional Module Designed by Students, as an Example of Didactical Transposition}

TNS subject is raised to refresh and evolve didactically (didactic transposition) previous knowledge of 5 blocks of contents included in the curriculum of Primary Education in Navarra as shown in BON [7], which are:

- Introduction to scientific activity

- The human body and health

- $\quad$ Living beings

- Matter and Energy

- Technology, objects and machines

Students work in small groups and select the most attractive block for them as a group. This is a strategy to encourage motivation. Then, they evolve the selected block, contextualized in a particular grade of Primary Education (6 to 12 year old students), in the last practical work, which is the design of the Instructional Module (IM) by developing a Knowledge Model, using Cmap Tools. For the design and development of the IM, students need to have some basic scientific knowledge provided by the specific CCMM designed to refresh their previous ideas and which are showed in section 3.1 (Figures 12, 13, 14 and 15): Biology (Living beings and human body); Physical contents (The nature of light); Chemical contents (Matter and energy) and Geological Contents (the structure of the Earth and technology). By developing the IM, we ensure that students work independently and acquire the skills for designing their own teaching materials in the future, developing an original knowledge model to apply in the near future with their primary school students.

Below, the typical root map of an IM (Figure 15) is showed, containing the theoretical framework of the subject TNS, the KM of the selected block and the Instructional Design; this last, including the principles of programming, implementation and assessment which are represented by the following concepts: contextualization, organization or programming in a timetable, objectives, contents, methodologies, activities (initial, processing and summarizing), assessment, glossary and references. This IM is developed by students in Figure 16 in which some of the resources are opened to show the possibilities offered by Knowledge Models as tools both for students and teachers.

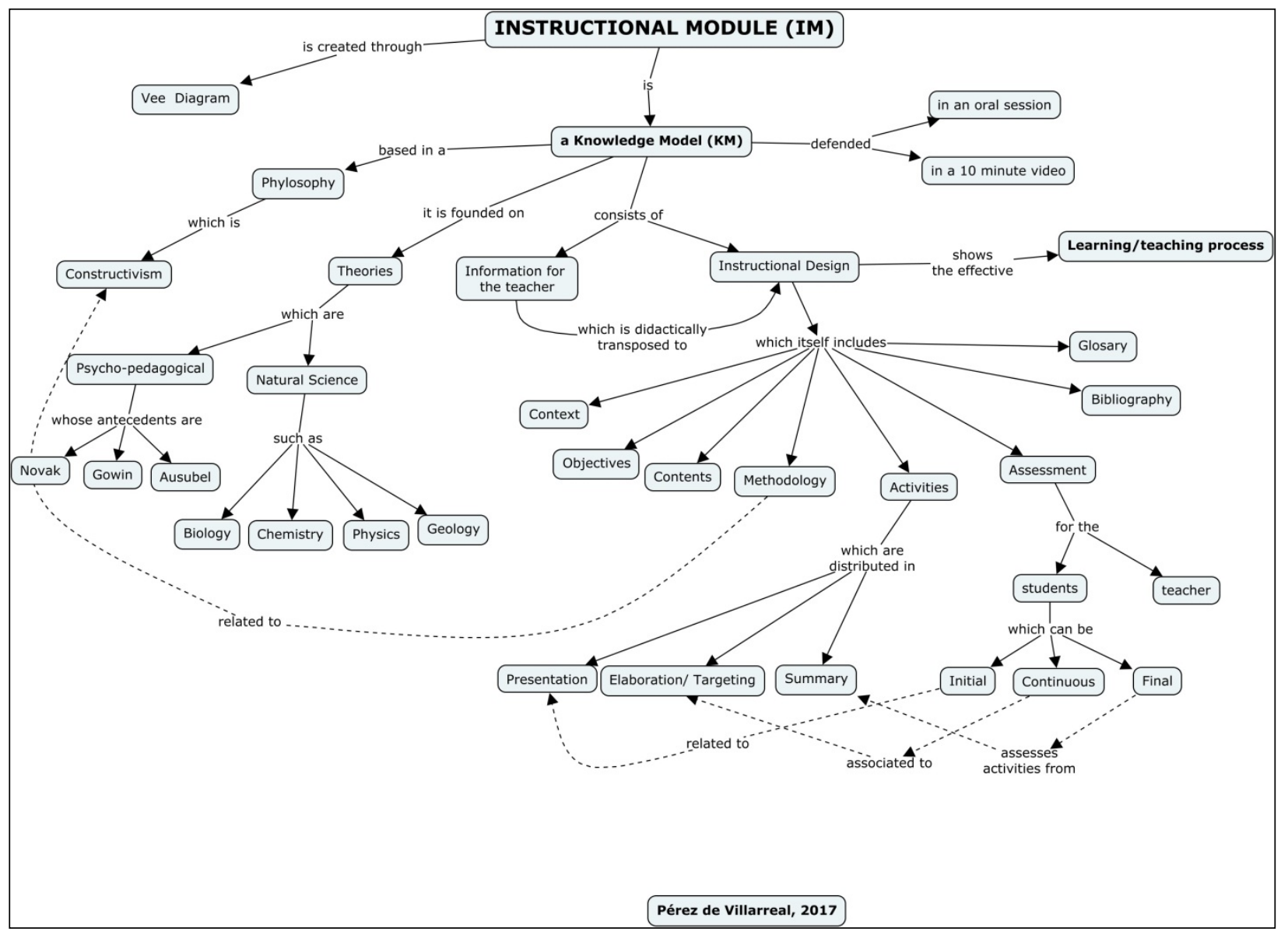

Figure 15. Example of the IM root map to be developed by a group of TNS students, including a Knowledge Model and the Instructional Design. Available at: http://cmap.unavarra.es/rid=1S1 MG8T9N-1 WG94V5-132/Instructional\%20Module.cmap 


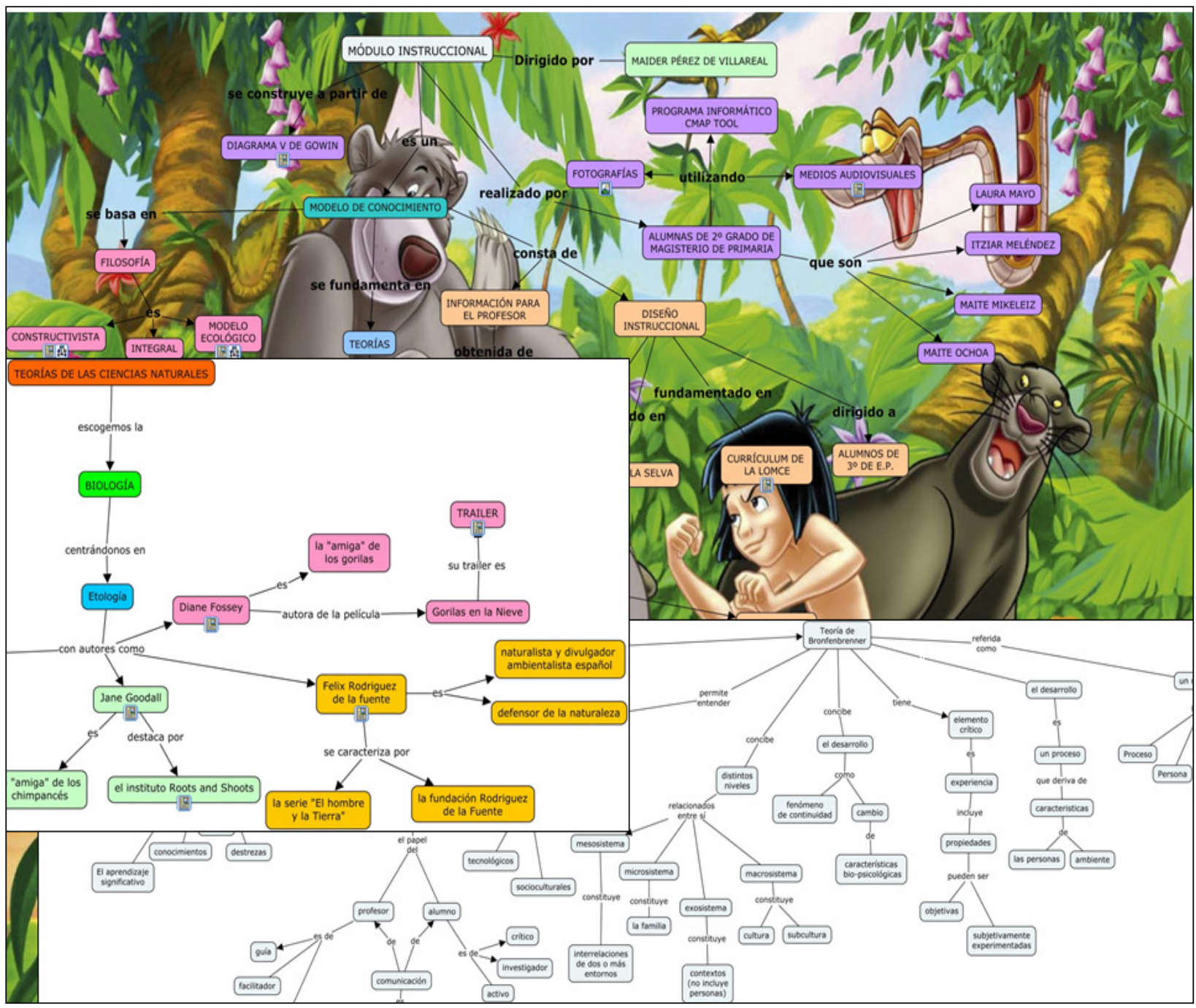

Figure 16. Example of the IM developed by a group of TNS students, including a Knowledge Model and the Instructional Design, which is the didactical transposition of the knowledge acquired as students, to be implemented when they become teachers. Available at: http://cmap.unavarra.es/rid=1Q351FYRV-5J4RKT-F3/M\%C3\%B3dulo\%20Instruccional.cmap

In this last figure, an example of the IMs developed by students is showed. This work performed by students at the end of the subject shows an original Knowledge model, containing transparent and substantial information, which has been transformed didactically. As Chevallard [9] described in his work, it follows the so-called transposition, through the development of initial, processing and summary activities, which are designed under a specific methodology, to become accessible to primary school students. Each group of students (4-5 people in each group) makes an oral presentation of their IM during 15 minutes

\subsection{Inquiry Results}

Finally, a survey was sent to students in order to check if they felt happy with the structure of the subject and with the theoretical and practical contents or if they had any suggestions for its improvement. The poll was filled by students who attended class in a particular day (30 students). It posed with 6 closed questions and 1 open question. Among the 6 closed questions, 22 students $(73,4 \%)$ considered the presentation of the TNS course through Cmap Tools was practical; 21 students $(70 \%)$ considered this format allowed them understand and study the contents of the three blocks of the course, better, comparing to the more conventional teaching style; 27 students $(90 \%)$, confirmed there was consistency in teaching the subject in the same format that it was intended they learnt, for its application in their future as teachers of Primary Education; only 2 people $(6,7 \%)$ wanted to study the theoretical contents in a more traditional teaching style; 25 students $(83,3 \%)$ confirmed that they would use what they learned in the course to make their teaching materials in the future; and 22 students $(73,3 \%)$, considered the teaching of the subject as a $\mathrm{KM}$, enabled them to achieve the necessary skills for becoming Science Teachers in Primary Education. 
The open question, was related to the quality of the teaching, being the question, "What do you suggest in order to improve the teaching of the subject TNS?". In this case, 6 students $(20 \%)$ did not answer, whereas 24 students $(80 \%)$ did. Overall they alluded to aspects related to the theoretical content of the course, to the practice, to the necessary time, the dynamism and to instructional tools. With regard to the theoretical content, 8 students $(26,7 \%)$ considered important to clarify the specific contents to study for the exam or written test; 3 students $(9 \%)$ wanted to explain more deeply some scientific concepts and 8 students $(2,7 \%)$ suggested less theoretical content; in the case of the practice, 5 students $(16,5 \%)$ wanted more practical sessions, with emphasis on the design of practical experiments held in the laboratory (3 students, $10,6 \%$ ) and the possibility of taking a trip to a Natural Science Museum or to a Natural Park (8 students, $2,7 \%)$; 4 students $(13,3 \%)$ indicated they missed more dynamism in class; with respect to the recommended instructional tools, 2 students $(6,7 \%)$ answered Cmap tools should not be the axis of the subject, and preferred to make the IM, without using the software; finally and regarding the timing, 3 students (9\%) agreed they needed more time for the explanations of scientific and practical contents.

\section{Discussion}

TNS is a compulsory subject of the educational program of the Bachelor's Degree of Primary Education (BDPE) at the Public University of Navarra (Navarra, Spain). It was considered a difficult subject by students, because they assume Science and Humanities cannot coexist. Our approach as University teachers has been to try to use the same instructional tools we teach our students, in order to build our subject, so that BDPE students, see the coherency and start imitating, by creating their own teaching material, understanding better the practicality and functionality provided by the use of instructional tools. The subject is structured in 15 theoretical sessions and 15 practical ones, combined so that the theoretical sessions have their continuity with the practices. It becomes learning-teaching (university)-learning-teaching (school) chain (didactic sequence) and we have to test if our proposal (using instructional tools for preparing teaching material and for teaching) is useful for our students. For that, we designed an inquiry which showed in general, students were more concerned about the theoretical contents for the exam or written test than for learning or acquiring knowledge. This fact, gives a clue for transforming the assessment and change students perspective, so that they rather want to know and get to a domain of knowledge as explained by Meichenbaum and Biemiller [23], than to only pass a exam. Although, perhaps this is just a question of maturity and in further research, we can check it in other subjects from the same field of "Knowledge of natural and social environment ", such as "Educational projects of the natural environment" in which students are older since this subject is taught in the third year of the degree.

The software applied, Cmap Tools, allows teachers to generate the conditions facilitating students to transform information in useful, substantive and transparent knowledge, to be integrated in their knowledge structure and in their long-term memory. Students play an active role, not only learning about the product and selecting the information, but through the process itself (metacognition), leaving behind the previous behaviorist-positivist model which favoured mechanical-rote learning and advocating a new model, cognitive-constructivist allowing meaningful and long life learning happen, as well as promoting critical thinking citizenship. During the LTP University teachers try to make BDPE students concerned of the power they will have for shaping the society of the future when educating children and for giving them valid instructional tools to apply when teaching STEM related subjects with the aim of approaching the real world through authentic practice. The constructivist philosophy illuminates the path to follow and authors, such as Novak [27], Ausubel and Gowin [19], provide the tools to create knowledge, remove misconceptions and associate emotions and learning. It has been a pleasant experience to adapt the subject to what it is being taught and we will take in consideration all the suggestions made by students for improving the subject with more practical training in laboratory, maybe visiting some Natural Science Museum or the Planetarium or taking a trip to a Nature Park in the surroundings. However, results have been very positive because students consider TNS provides them with the competences for becoming Primary Education teachers, they appreciate the consistency of being taught in the way they will have to teach in the near future, they seem motivated and committed to improving the quality of education and adapting their teaching material to the time, and a great percentage of students confirm they will apply $\mathrm{KM}$ in their future teaching activities.

Alluding to the Ecology of Practices (Bronfenbrenner, [8]; Kemmis and Mutton [22]; Pérez de Villarreal, [35]), we consider TNS subject is a dynamic living being who needs to be fed and to continue raising and interacting, and any changes made, are always for the evolution of the creature and its adaptation to the environment and in that, innovation is the path to follow.

\section{Conclusions}

The presentation of the subject TNS as a knowledge model, leads a conceptual change in students. Even if at first, it is hard to take them away from the comfort zone (the way how they were taught before), the results of the 
survey confirm it is coherent to teach teachers to be students in the way they should teach in the near future, by building their own teaching material. This material would be original, transparent, and free of misconceptions and it should be ready to be transponed didactically in an increased level of complexity through well designed activities sequences following a well-planned instructional design. The $\mathrm{KM}$ is an example of what students can develop to create their teaching material and it can be valid to inform policy makers and education providers when designing and delivering the subjects of the curriculum which involve STEM subjects. It is also noteworthy this teaching strategy engages students in their learning and promotes their motivation and metacognition; therefore it could be used as a recommendation to follow for curriculum designers, as it is a valid tool for curricular adaptations and assessment in students with special needs, such as those affected by rare diseases or gifted students.

In general, most students feel happy with applied teaching strategy, and in order to accomplish all the suggestions, more time than a semester would be needed. However, it has been a very positive experience and providing metacognitive tools, such as Vee diagram, concept mapping and the software Cmap Tools will help students as future teachers in their Learning Teaching Process (LTP). This can be the beginning of a new way of teaching, in which information can be transformed in useful knowledge and students become independent learners.

\section{REFERENCES}

[1] Anta De, G. (2001). Esquemas y mapas conceptuales en el aula de ciencias. Alambique. Didáctica de las Ciencias Experimentales, vol. 15, n.3, 22-30.

[2] Albisu S., San Martín, I., and González, F. (2006). Aplicación de los Mapas Conceptuales y de la V de Gowin en la Elaboración de Módulos Instruccionales en Alumnos de Magisterio. Proceedings of the Second International Conference on Concept Mapping. San José, Costa Rica, pp.48-50.

[3] Ausubel, D., Novak, J. y Hanesian, H. (1983). Psicología Educativa: un punto de vista cognitivo. México: Trillas

[4] Barriga, F. y Hernández, G. (1999). Estrategias docentes para un aprendizaje significativo. Una interpretación constructivista. México: Mcgraw-Hill.

[5] Belletich, O.; Pérez de Villarreal, O. (2015). El imaginario colectivo de la educación en la formación inicial de maestros, pp.95-106. En: Sánchez Sáinz-Trápaga, C., Construyendo la Nueva enseñanza superior, V.2. Madrid: McGraw Hill.

[6] Belletich, O.; Pérez de Villarreal, M.; Zufiaurre, B. (2013). How to read assessment criteria when dealing with culturally diverse pupils? An analysis based on a Spanish context . Universitas Tarraconensis. Revista de Ciencies de
l’Educacio / 1135-1438. XXXVIII, Diciembre.

[7] BON: Boletín Oficial de Navarra. Currículo de las enseñanzas de Educación Primaria en la Comunidad Foral de Navarra. number 174, 5 de September 2014

[8] Bronfenbrenner, U. (1979). Ecology of Human development: Experiments by nature and design. Cambridge: Harvard Press.

[9] Chevallard, Y. (1997). La transposition didactique. Du savoir savant au savoir enseigné. Ed. Aique.

[10] Gardner, H. (1983). Frames of mind: The Theory of Multiple Intelligences. New York: Basic Books.

[11] Gardner, H. (2003). La inteligencia Reformulada. Las inteligencias múltiples en el siglo XXI. Barcelona: Paidós ibérica.

[12] Godino, JD, C Batanero, C., Contreras, A., Estepa, A., Lacasta, E., and Wilhelmi, M.R. (2013). Didactic engineering as design-based research in mathematics education. Proceedings of the CERME, 8.

[13] Goleman, D. (1996). Inteligencia emocional. Barcelona: Editorial Kairós, S.A.

[14] Goleman, D. (2009). Inteligencia Ecológica. Barcelona: Editorial Kairós, S.A

[15] González, F (2008). El mapa conceptual y el diagrama UVE: Recursos para la Enseñanza Superior en el Siglo XXI. Editorial Narcea: Madrid.

[16] González, F., Guruceaga, A., Pozueta, E., and Lara, R (2009). Making visible good teaching practices of a university lecturer by using concept mapping. International Association for the Development of Advances in Technology IADAT. 5th IADAT International Conference on Education, Bilbao (Spain), June 24-26.

[17] González, F., Morón, C., and Novak, J. (2001). Errores conceptuales. Diagnosis, tratamiento y reflexiones. Pamplona: Ediciones Eunate.

[18] González, F., and Zuasti, J. (2008). The Running of the Bulls. A Practical Use of Concept Mapping to Capture Expert Knowledge. Proceedings of 3rd International Conference on Concept Mapping. Tallin, Helsinki, pp. 242-245.

[19] Gowin, D. B. (1981). Educating. Ithaca, Nueva York: Cornell University Press. Trad. cast., 1985. Hacia una teoría de la educación. Argentina: Ediciones Aragón.

[20] Guardian, B. y Ballester A. (2011). UVE de Gowin instrumento meta-cognitivo para un aprendizaje significativo basado en competencias. Revista Electrónica d'Investigació i Innovación Educativa i Socioeducativa vol. 3, n. 1. 51-62

[21] Herrera, E. and Sánchez, I. (2012). La UVE de Gowin como instrumento de aprendizaje y evaluación de habilidades de indagación en la unidad de fuerza y movimiento. Paradigma 33 (2), pp. 101-125.

[22] Kemmis, S., Mutton R. (2009). Education for sustainability (EfS): Practice and Practice architectures. Charles Sturt University. Unpublished paper. Wagga Wagga (Australia).

[23] Meichenbaum, D., and Biemiller, A. (1998). Nurturing 
Independent Learners. Helping Students take Charge of their Learning. Cambridge, Massachusetts. Brookline Books.

[24] Moreira, M. (2010). ¿Por qué conceptos? ¿Por qué aprendizaje significativo? ¿Por qué actividades colaborativas? y ¿Por qué mapas conceptuales? Qurriculum, vol. 23. 9-23, Tenerife: Universidad de La Laguna. Servicio de Publicaciones

[25] Moreira, M. (2005). Aprendizaje Significativo Crítico. Instituto de Física Universidad Federal de Porto Alegre, Brasil: Editora da UFRGS.

[26] Moreira, M. (2006). A teoria da aprendizagem significativa e sua implementação em sala de aula. Brasília: Editora da UnB

[27] Novak, J. (1982). Teoría y práctica de la educación. Alianza Universidad: Madrid.

[28] Novak, J. y Gowin D. (2005). Aprendizaje significativo: Técnicas y aplicaciones. Ediciones Pedagógicas. USA: Cincel

[29] Novak, J. y Gowin, D. (1988). Aprendiendo a aprender.117-10 Barcelona, España: Ediciones Martínez Roca, S.A.

[30] Novak, J. and Cañas, A (2006): The Theory Underlying Concept Maps and How to Construct Them (Technical Report IHMC CMap Tools 2006-11). Florida Institute for Human and Machine Cognition.

[31] Novak, J. (1998). The pursuit of a Dream: Education Can Be Improved. In J. Mintzes, Wandersee J. and Novak, J. Teaching Science for Understanding. A Human Constructivist View. San Diego: Academic Press, pp. 3-28.

[32] Novak, J. D. (1998). Learning, creating, and using knowledge: Concept Maps as Facilitative Tools in Schools and Corporations. Mahweh, NJ: Lawrence Erlbaum Associates.

[33] Novak, J. D., \& Gowin, D. B. (1984). Learning How to
Learn. New York: Cambridge University Press.

[34] Ontoria, A. (C) (2001). Mapas conceptuales. Una técnica para aprender. Madrid: Narcea.

[35] Pérez de Villarreal, M. (2016). Teaching sciences positively (pp. 133-155). In: Zufiaurre, B. and Pérez de Villarreal, M. Positive Psychology for Positive Pedagogical Actions. New York: Nova Publishers.

[36] Pérez de Villarreal, M., and Zufiaurre, B. (2015). What about education and schooling for sustainable development?. Advances in Social Sciences Research Journal, 2 (7), pp. 65-78.

[37] Posner, G., Strike, K., Hewson, P., and Gertzog, W. (1982). Accommodation of a scientific conception: toward a theory of conceptual change. Science Education, 62 (2), pp. 211-227.

[38] Rodríguez, M., Caballero, C. y Moreira, M. (2010). La teoría del aprendizaje significativo: un referente aún actual para la formación del profesorado. Actas del I Congreso Internacional Reinventar la formación docente. Universidad de Málaga; 589-603.

[39] Sánchez, I. (1999): El Mandala y la Uve de Gowin en la Enseñanza de la Física. Paideia, vol. 27, 47-60.

[40] Villar, L., and Alegre, O. (2004). Manual para la Excelencia en la Enseñanza Superior. Madrid: Mc Graw Hill.

[41] Wandersee, J. H., Mintzes, J. J., \& Novak, J. D. (1994) Learning: Alternative Conceptions. In D. L. Gabel (Ed.), Handbook on Research in Science Teaching (pp. 177-210). New York: Macmillan.

[42] Zabalza, M. A. (2004). A Didáctica Univeresitaria. Un espazo disciplinar para o estudo e mellora da nosa docencia. Santiago de Compostela: Universidad de Santiago de Compostela.

[43] Zufiaurre, B.; Belletich, O. (2014). Neoliberal imaginarium for conservative educational practices. Knowledge Cultures, 2(4), pp. 45-63. 